\title{
Accounting for forest management in the estimation of forest carbon balance using the dynamic vegetation model LPJ-GUESS (v4.0, r9333): Implementation and evaluation of simulations for Europe.
}

\author{
Mats Lindeskog ${ }^{1}$, Fredrik Lagergren ${ }^{1}$, Benjamin Smith $^{1,2}$ and Anja Rammig ${ }^{3}$ \\ $5 \quad{ }^{1}$ Department of Physical Geography and Ecosystem Science, Lund University, Sweden. \\ ${ }^{2}$ Hawkesbury Institute for the Environment, Western Sydney University, Penrith NSW, Australia. \\ ${ }^{3}$ TUM School of Life Sciences Weihenstephan, Technical University of Munich, Freising, Germany \\ Correspondence to: Mats Lindeskog (mats.lindeskog@nateko.lu.se)
}

Abstract. Global forests are the main component of the land carbon sink, which acts as a partial buffer to $\mathrm{CO}_{2}$ emissions into the atmosphere. Dynamic vegetation models offer an approach to making projections of the development of forest carbon sink capacity in a future climate. Forest management capabilities in dynamic vegetation models are important to include the effects of age and species structure and wood harvest on carbon stocks and carbon storage potential. This article describes the introduction of a forest management module in the dynamic vegetation model LPJ-GUESS. Different age- and species-structure setup strategies and harvest alternatives are introduced. The model is used to represent current European forests and an automated harvest strategy is applied. Modelled carbon stocks and fluxes are evaluated against observed data at the continent and country levels. Including wood harvest in simulations increases the total European carbon sink by $32 \%$ in 1991-2015 and improves the fit to the reported European carbon sink, growing stock and net annual increment (NAI). Growing stock $\left(156 \mathrm{~m}^{3} \mathrm{ha}^{-1}\right)$ and NAI $\left(5.4 \mathrm{~m}^{3} \mathrm{ha}^{-1} \mathrm{y}^{-1}\right)$ densities in 2010 are close to reported values, while the carbon sink density in $2000-2007\left(0.085 \mathrm{kgC} \mathrm{m}^{-2} \mathrm{y}^{-1}\right)$ is $63 \%$ of reported values. The fit of modelled values and observations for individual European countries vary, but NAI is generally closer to observations when including wood harvest in simulations.

\section{Introduction}

Forests globally provide ecosystem services including provision of timber, fuel and water, regulation of local climate and hydrology, carbon sequestration, support of biodiversity and recreation (Bonan 2008; Mori et al., 2017). The effects of climate change on forest productivity and biodiversity may be predicted to be negative due to increased evapotranspiration and reduced rainfall in many forested areas, an increase in extreme events like drought, wild-fires, storms and insect attacks and local or regional extinctions of plant and animal species (Easterling et al., 2000; Seidl et al., 2011; Anderegg et al., 2015; Urban 2015). On the other hand, productivity may increase due to the fertilising effect of increased nitrogen deposition and higher atmospheric $\mathrm{CO}_{2}$ levels (Zaehle and Dalmonech, 2011; Luyssaert et al., 2008) as well as shifts in tree species composition and longer growing seasons at high latitudes caused by higher temperatures (Sitch et al., 2015; Morin et al., 2017).

Forests make up the largest portion of the current land carbon sink, and are estimated to have absorbed 20-50\% of $\mathrm{CO}_{2}$ emitted by fossil fuel combustion and industry during the first decade of this century (Pan et al., 2011; Le Quéré et al., 2018; Pugh et al., 2019). The suggested basis for this carbon uptake is the recent history of the drivers increasing productivity mentioned above, especially increased $\mathrm{CO}_{2}$, and the recovery of carbon pools in regrowth forests (Pugh et al., 2019). The size of the forest carbon sink has been estimated by either book-keeping methods (Pan et al., 2011; Houghton et al., 2012) or by global vegetation models (Luyssaert et al., 2008; Shevliakova et al., 2009; Pugh et al., 2019) but this sink is associated with relatively large uncertainties, resulting in differing estimates using different approaches and models. Key uncertainties include the magnitude of $\mathrm{CO}_{2}$ fertilisation 
— which may be limited by soil availability of nutrients such as N and P (Zaehle and Dalmonech, 2011; Jiang et al., 2020) — and the extent of shifting cultivation in the tropics (Heinimann et al., 2017). While the net atmosphere-to-land flux $\left(\mathrm{F}_{\mathrm{L}}\right)$ is relatively well constrained by measurements, large uncertainties in the net land-use and land-cover flux $\left(\mathrm{F}_{\mathrm{LULCC}}\right)$ make the size of the residual (land) $\operatorname{sink}\left(\mathrm{F}_{\mathrm{RL}}\right)$ itself uncertain $\left(\mathrm{F}_{\mathrm{L}}=\mathrm{F}_{\mathrm{RL}}-\mathrm{F}_{\mathrm{LULCC}}\right)$ (Arneth et al., 2017).

Forests cover $33 \%$ of the Europe's land area (Forest Europe, 2015) and store approximately $13 \mathrm{PgC}$ in vegetation and $28 \mathrm{PgC}$ in soils (Pan et al., 2011). The carbon sink of European forests in 2000-2007 has been estimated at $0.27 \mathrm{PgC}^{-1}$ or about $12 \%$ of the global carbon sink of established forests (Pan et al., 2011). Europe has been identified as a region where regrowth forests dominate carbon sequestration (Pugh et al., 2019) and has a history of thousands of years of human impact on forest structure and species composition (Perlin, 2005). Forest management practices of the past few hundred years are relatively well documented (McGrath et al., 2015). Depending on the region, different management strategies are applied (Cardellini et al., 2018). The relatively young tree age and the removal of wood in managed forests influence carbon stocks and fluxes e.g. by increasing productivity and reducing self-thinning and age-related mortality and litter production compared to pristine forests (Zaehle et al., 2006). In addition to the effects on atmospheric $\mathrm{CO}_{2}$, forest management influences local climate by changing albedo, evapotranspiration and surface roughness (Luyssaert et al., 2014).

Dynamic global vegetation models (DGVMs) provide a potential framework for predicting the combined effects of climate and forest management scenarios on forest ecosystem structure and carbon balance. Based on such information, the potential of forest landscapes to contribute to climate change mitigation by maintaining or enhancing carbon sinks, and to climate adaptation through sustained production of forest products and other ecosystem services in the face of climate change, can be assessed. Applications of DGVMs to represent climate responses of potential natural vegetation (PNV) have been shown in the past, for example as a basis for nature conservation planning (Hickler et al., 2012). Human management of land, including cropland, pasture and managed forest, has been introduced in a number of DGVMs (Bondeau et al., 2007; Bellassen et al., 2010; Lindeskog et al., 2013; Arneth et al., 2017). Key elements required to represent managed forests in a DGVM framework include the ability to initialise a simulation with historical land use, to represent age/size structure of forests stands and their change over time, to account for tree species composition and to apply silvicultural treatments that modify stand composition and structure, like planting, thinning and harvesting.

LPJ-GUESS (Smith et al., 2001; Smith et al., 2014) is a second-generation DGVM incorporating a detailed representation of forest ecosystem composition and stand dynamics, suitable for the implementation of a forest management scheme. It captures the distribution of European PNV at species level and can make projections of vegetation shifts under future climate scenarios (Hickler et al., 2012). The model has been shown to represent vegetation growth and succession successfully (Smith et al., 2014). It has been used to estimate forest vulnerability to climate change (Seiler et al., 2015) and carbon mitigation potential of regrowth forests and forests under alternative management scenarios (Pugh et al., 2019; Krause et al., 2020). Earlier versions of LPJ-GUESS have been modified to enable analysis of clearcut forest management and the effects of wind damage and insect outbreaks (Lagergren et al., 2012; Jönsson et al., 2012). In this study, we describe the implementation of forest management capabilities in LPJ-GUESS v.4.0, which considers, in addition to detailed carbon- and water-cycle processes, nitrogen-cycling and nitrogen-limitation (Smith et al., 2014). Model alternatives for forest stand initialisation (land-use history and species- and age-distribution) and silvicultural management (detailed and automated harvest strategies) are presented in detail. Using an automated thinning and clearcut approach for European forests, we compare modelled carbon stocks and fluxes with observational data and explore the performance under a changing climate. 


\subsection{General description of LPJ-GUESS and overview over simulated processes}

LPJ-GUESS (Smith et al., 2001; Smith et al., 2014) simulates the dynamics of terrestrial vegetation and soils across a regional or global grid, forced by meteorological inputs and soil physical properties. In the original implementation, each grid cell encompasses a landscape of natural, climatically determined vegetation (PNV). A number (5-100) of replicate patches, nominally 0.1 ha in size, represent disturbance-related variation in stand age across the wider landscape of a grid cell. In each patch, age cohorts of tree and shrub plant functional types (PFTs) or species and grass PFTs compete for light, water, nitrogen and space (Fig. 1). In its original version, the model only simulates PFTs that capture the major vegetation zones globally. The parameter set of these PFTs has been extended to simulate the most important tree species in northeastern USA (Hickler et al., 2004) and Europe (Koca et al., 2006; Hickler et al., 2012) as distinct PFTs. The new functionality defined in this paper can operate equally on individual tree species or more generalised PFTs. Hereinafter 'species' is thus used synonymously with 'PFT'. The canopy is represented as a multi-layered structure. Leaves, fine roots and stem heartwood and sapwood are represented as dynamic pools for each age cohort of each PFT. Branches and course roots are not explicitly discriminated but are implicit in the wood biomass pool. The patches are subject to stochastic vegetation-destroying disturbance events (representing e.g. wind-storms or landslides) with a prescribed return interval (e.g. 100-400 years). Disturbance results in the loss of vegetation in a patch, after which a secondary succession of grass and tree PFTs follows. Establishment is affected by forest floor light conditions and is subject to PFT-specific environmental envelopes defined by bioclimatic limits. A slightly different set of bioclimatic limits govern survival (Table A1). Growth-efficiency-, selfthinning-, background- (age-related) and fire mortality are applied to individual cohorts. Establishment and mortality have a stochastic component. Soil carbon and nitrogen cycling are based on the CENTURY model (Parton et al., 1993) and soil hydrology on a two-layered "leaking bucket" model. A soil mineral nitrogen pool is provided by atmospheric deposition, biological nitrogen fixation and gross nitrogen mineralisation of soil organic matter. Plant nitrogen uptake is driven by the demand from photosynthesis and biomass growth, and is limited by the supply from the soil mineral nitrogen pool. The nitrogen dynamics in the model are described in detail by Smith et al. (2014).

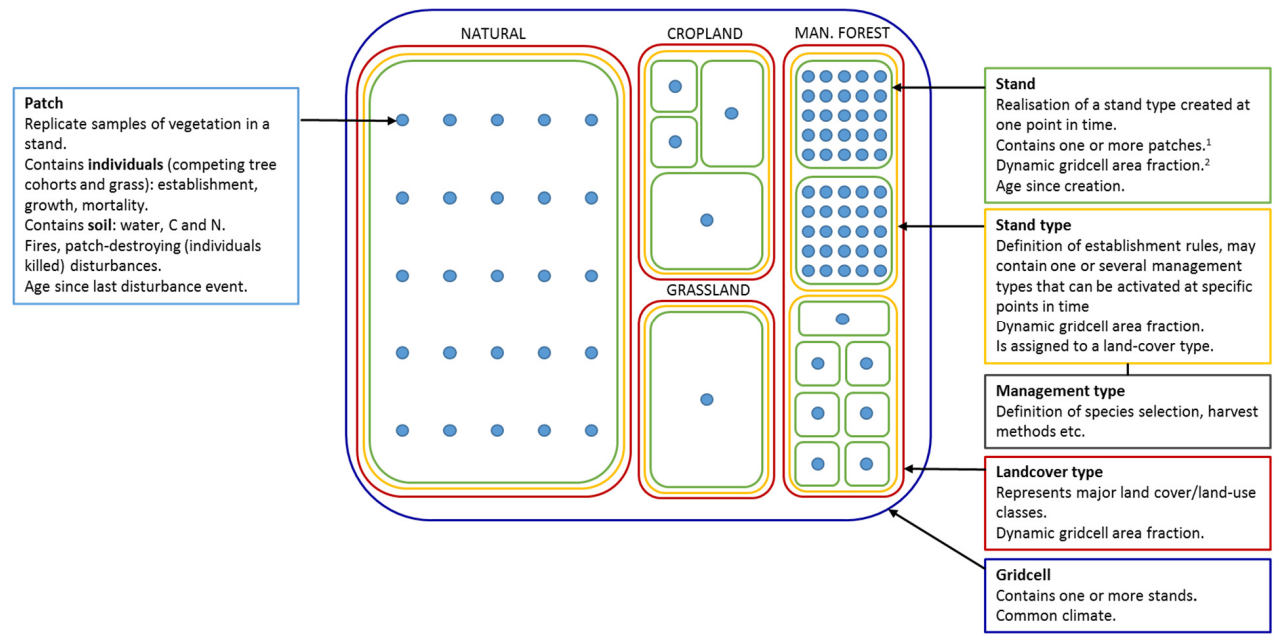

100 Figure 1. Data structures in LPJ-GUESS relevant for this study. ${ }^{1}$ Patch number is defined separately for PNV and secondary stands. If a secondary stand is created from PNV or managed forest with intact vegetation, the patch number of the mother stand is used. ${ }^{2}$ Stands belonging to stand types with trees can only be reduced in size. Expansion of such stand types results in new stands. 
Different land-use/land-cover types in addition to PNV are represented in the model by stand types with different management, e.g. cropland, pasture and managed forest (Lindeskog et al., 2013, Fig. 1). Transitions between different stand types may occur at any point in time, according to historic land-use data, to recreate land-use history. When a potentially forested stand type area expands, new stands are created, keeping the soil history from the previous stand type intact and allowing vegetation succession to proceed from bare ground (in most cases, but cf. 2.2). In modelled wood harvest events $66 \%$ of wood biomass and $30 \%$ of leaf biomass is removed from the stand and the rest remains as litter. Removed leaf biomass and part of wood biomass (by default 67 $\%$ ) is oxidised the same year. The remaining wood biomass is put into a product pool with a turnover rate of $4 \%$ per year.

\subsection{Forest structure initialisation routines}

Forest stand age- and species distributions can be achieved in the model by several alternatives, utilising the structure of a previous PNV stand or defining a new age- and species structure at various levels of detail.

\subsubsection{Stand creation}

A managed forest stand may be created in the model by two different options (Fig. 2, B1). By cloning the stand of origin, the complete state with all patches intact is inherited by the secondary stand. If the origin is previous woodland (PNV or secondary forest), a cutting scheme may start with the existing tree structure, optionally cutting unwanted species. In the other alternative, tree growth starts from bare ground after an initial clearcut or when expanding on former cropland or pasture. In this case (with an even-age stand and if disturbance and fire are turned off), the secondary stand can in many cases be modelled by a smaller number of replicate patches since there is usually no random variation in the timing of management events.

\subsubsection{Secondary forest age structure}

Managed forest stands with an uneven age structure can be represented in the model by different options. An age structure may be created in individual patches by thinning (enabling regeneration by increased light at the forest floor) at defined intervals during an initialisation period, allowing for competition between both cohorts and species (Fig. 3a). To achieve an age structure among patches within a stand, the age structure of PNV, achieved during the spinup by patch-distroying disturbance events, may be conserved after the conversion to managed forest if the cloning functionality is used, copying the PNV stand with the semirandomised age structure intact (Fig. B1). Alternatively, multiple patches in a secondary stand may be clearcut successively at regular intervals during an initialisation period (Fig. 3b). In the final approach, a prescribed age structure, either representing a specific moment in time, or a historical development, may be created among stands representing a stand type, using land-cover change input data (Fig. 3c).

\subsubsection{Secondary forest species composition}

Species mixtures may be defined either at the management type level (Fig. 1), using predefined planting densities for individual species and/or later cuttings to achieve prescribed relative abundances of the different species within a patch (Fig. 4a, see below), or at the landscape level, using land-cover input data to achieve predefined mixtures of monocultures (Fig. 4b), or a combination of both of these options. 
https://doi.org/10.5194/gmd-2020-440

Preprint. Discussion started: 27 January 2021

(c) Author(s) 2021. CC BY 4.0 License.

Vegetation C

(a)

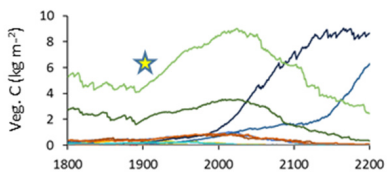

(b)

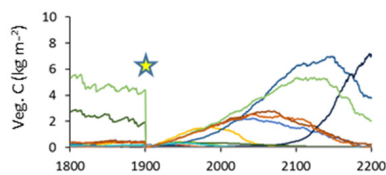

(c)

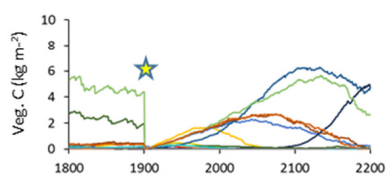

(d)

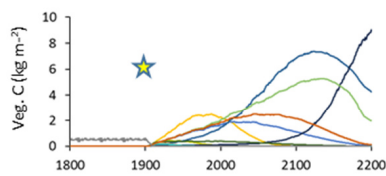

(e)

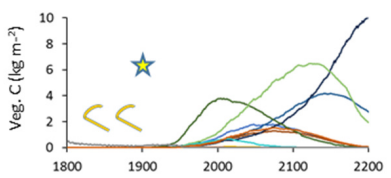

$$
\begin{aligned}
& \text { - Bet_pen - Bet_pub } \\
& \text { Bet_pen - Bet_pub } \\
& \text { - Car_bet - Cor_ave } \\
& \text { — Pag_syl - Fra_exc } \\
& \text { - Pop_tre Que_rob } \\
& \text { - Til_cor Ulm_gla } \\
& \text { Grass cutting }
\end{aligned}
$$

C pools
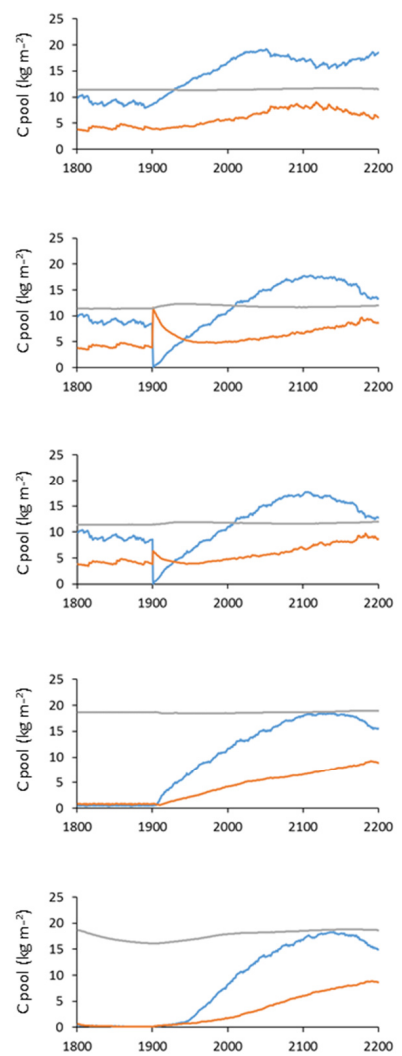

Veg.C
Litter C
Cumulative $\mathrm{C}$ flux
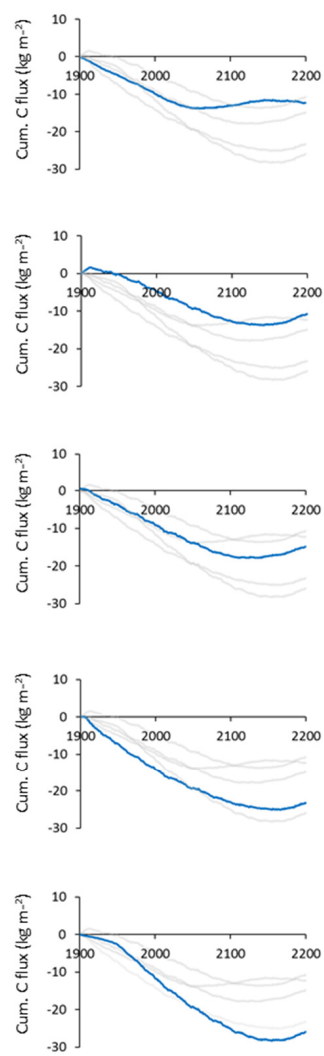

Figure 2. Examples of different histories and initialisations of forest stands in LPJ-GUESS at a South Swedish site $\left(13.75^{\circ} \mathrm{E}, \mathbf{5 5 . 7 5}^{\circ} \mathrm{N}\right)$ with CRU-NCEP climate (recycled 1986-2015 climate after 2015). Disturbance and fire was turned off in the managed forest stands. Vegetation carbon, carbon pools (vegetation, litter and soil), and cumulative total carbon flux (negative values correspond to an uptake from the atmosphere) are shown for forest stands created in 1901 from PNV or grassland. (a) PNV stand with 25 patches cloned, keeping age and species structure from spinup period intact. (b) Clearcut of PNV stand. Harvested wood and branches left as litter. Succession from bare ground. (c) Clearcut of PNV stand. Harvested wood and part of branches removed. Succession from bare ground. (d) From grassland with 1 patch. (e) From intensively cut meadow with 1 patch, 100\% of leaves cut each year in 1800-1900. Species/PFTabbreviations: Bet_pen Betula pendula, Bet_pub Betula pubescens, Car_bet Carpinus betulus, Cor_ave Corylus avellana, Fag_syl Fagus sylvatica, Fra_exc Fraxinus excelsior, Pic_abi Picea abies, Pin_syl Pinus sylvestris, Pop_tre Populus tremula, Que_rob Quercus robur, Til_cor Tilia cordata, Ulm_gla Ulmus glabra; C3_gr C3 grass. 
(a)

$\begin{array}{lcc} & \text { Age } & \text { Stand } \\ \text { Patch } & \text { Stand type } & \text { distribution } \\ & \text { year } 2000\end{array}$
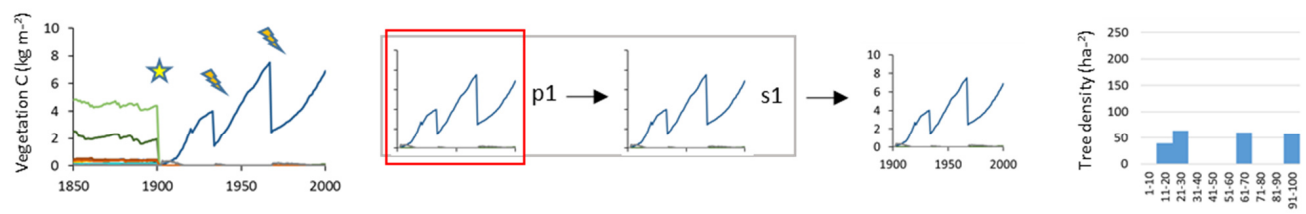

(b)
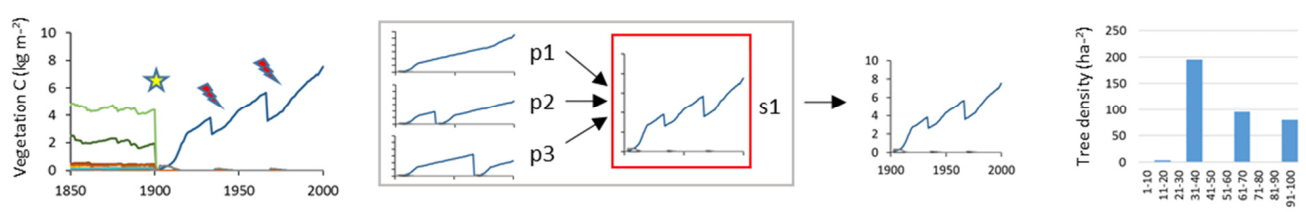

(c)
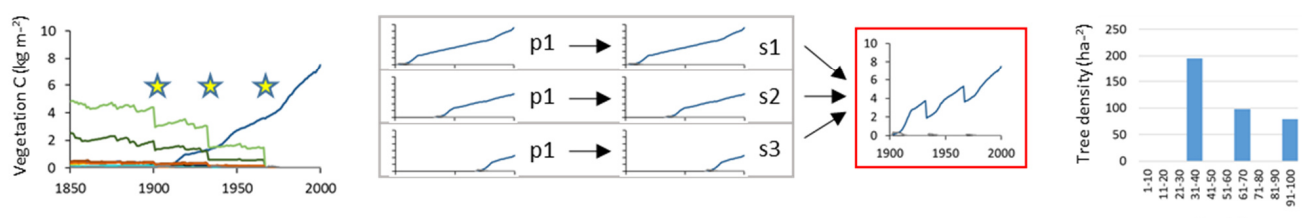

ฟ New stand from PNV

Age (y)

* Clearcut

\& Thinning

Figure 3. Examples of age structure setup at three different structural levels, patch, stand and stand type. Beech monocultures are created from clearcut of PNV. The target in year 2000 was three cohorts of 100, 67 and 33 years. (a) Within-patch. One secondary stand with 1 patch created in 1901. Thinnings in 1933 and 1967. Age structure depends on timing of increased light and subsequent reestablishment of seedlings. (b) Among-patch. One secondary stand with 3 patches created in 1901. Clearcut in patches 2 and 3 in 1933 and 1967 (evenly spread age distribution). (c) Among-stand. Three secondary stands with 1 patch created in 1901, 1933 and 1967. Age structure from area fraction input. Location, climate input and species in PNV as in Fig. 2.

\subsection{Forest management routines}

Depending on the level of detail in historic forest management input data or, in simulations of future scenarios, whether the management should be able to adapt to a changing climate or other factors, various model alternatives are available.

\subsubsection{Simplified clearcut forestry}

A simplified method to represent forestry using global wood harvest input data (e.g. harvested area) is achieved by creating secondary forest stands after clearcutting either a PNV stand or other secondary forest stands, representing cutting of primary or secondary forest, respectively. In cutting events, looping through the stands, these are cut according to stand age rules (cut oldest or youngest stands first, avoid cutting stands younger than 15 years old), allowing the allocation of wood harvest to primary forest and mature or young secondary forest. This method was used with LUH2 input data by Pugh et al., (2019). 
(a)
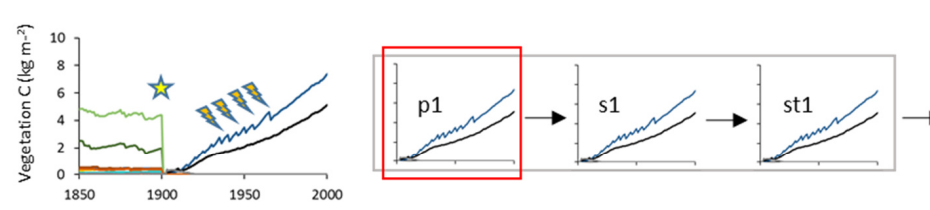

Patch

Stand

Stand type

Forest

Species

distribution

year 2000

(b)
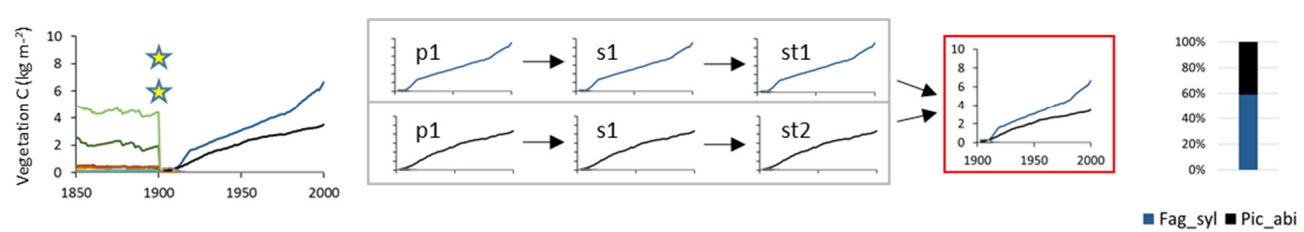

约 New stand from PNV

\& Thinning

Vegetation C

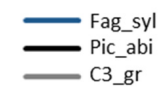

Figure 4. Examples of species structure setup at the patch and forest level. Beech-spruce 60-40 \% mixes are created after clearcut of PNV. (a) Within-patch; One secondary stand with 1 patch created in 1901. Mixed beech-spruce with selective thinning (target cutting 60/40 \%). (b) Among-stand types; Two secondary stands (beech and spruce monocultures) with 1 patch created in 1901 with $60 \%$ and $40 \%$ area fractions. Species abbreviations: Fag_syl Fagus sylvatica, Pic_abi Picea abies; C3_gr C3 grass. Location, climate input and species in PNV as in Fig. 2.

\subsubsection{Detailed forestry}

A number of forest management options can be selected at the stand type or management type level in the LPJ-GUESS instruction text file required to run a simulation (Table 1).

\subsubsection{Species selection}

175 A forest stand may contain a full selection of tree species (as in PNV) or a selection of species defined in the management type. After a clearcut event, or after creating a new forest stand from bare ground/grassland, selected species may be planted at defined sapling densities with or without the additional need to fall within the envelope of the bioclimatic limits that govern PFT establishment in PNV mode (Table A1). Alternatively, the standard establishment method can be used. After the initial planting/establishment, re-establishment can be optionally enabled or disabled for selected and unselected species. If several tree species are selected, it is possible to define a target relative abundance for each species (relative biomass) and apply selective cutting (Fig. 4a). Start and end calendar years for this treatment may also be defined.

\subsubsection{Clearcut forestry}

A fixed rotation period is defined, at the end of which a clearcut takes place (Fig. 5a). Alternatively, clearcut may be triggered by attainment of a prescribed stand density limit (Fig. 5b). The timing of a number of thinning events (default 5) may be defined as 
fractions of the rotation period in the case of a fixed rotation period. The harvest amount (strength) for such thinning events is defined as a fraction of current biomass, with the option of different settings for selected and unselected species. At each thinning event, trees may be cut using alternative strategies. Size/age criteria: (1) old or big trees first; (2) young or small trees first; (3) a specified harvest amount pertaining to trees above a specified diameter limit only; (4) all sizes/ages cut equally, may be combined with species criteria: (1) selected species first; (2) unselected species first; (3) separatly defined harvest amounts for selected and unselected species; (4) shrubs and shade-intolerant species first; (5) all species cut equally (Fig. 5a).

Table 1. Detailed forest management options. ${ }^{1}$

\begin{tabular}{|c|c|c|}
\hline \multicolumn{3}{|l|}{ Management option } \\
\hline Species selection & \multicolumn{2}{|c|}{ Allow all species/PFTs or define selection of species } \\
\hline Planting & \multicolumn{2}{|c|}{$\begin{array}{l}\text { After clearcut only; setting planting densities of selected species with or without climatic limits or } \\
\text { use model's standard establishment }\end{array}$} \\
\hline Re-establishment & \multicolumn{2}{|c|}{ All species/species in selection/none } \\
\hline Harvest system & \multicolumn{2}{|c|}{ Clearcut/Continuous } \\
\hline Cuttings & \multicolumn{2}{|c|}{ Two separate cutting phases of rotation time and thinnings: } \\
\hline & \multicolumn{2}{|c|}{$\begin{array}{l}\text { Regeneration phase (Clearcut harvest system, optional for Continuous harvest system) } \\
\text { Continuous phase (Continuous harvest system only) after specified time }\end{array}$} \\
\hline Rotation time & \multicolumn{2}{|c|}{ Period of thinning (+clearcut) loop } \\
\hline \multirow[t]{5}{*}{ Thinnings } & 1. Detailed: & \\
\hline & Timing & fraction of rotation time \\
\hline & Strength & fraction of biomass (separate values for selected/unselected species possible) \\
\hline & Preferences: & $\begin{array}{l}\text { young/old first } \\
\text { small/big first } \\
\text { selected/unselected species first } \\
\text { shrubs and shade-intolerant first } \\
\text { diameter limit (cut only trees above a diameter limit) }\end{array}$ \\
\hline & \multicolumn{2}{|c|}{ 2. Automated: Self-thinning rule-based method } \\
\hline Clearcut & \multicolumn{2}{|c|}{$\begin{array}{l}\text { 1. Fixed rotation time } \\
\text { 2. Automated: Tree density limit }\end{array}$} \\
\hline $\begin{array}{l}\text { Cut to species } \\
\text { distribution target }\end{array}$ & \multicolumn{2}{|c|}{$\begin{array}{l}\text { Relative biomass of selected species monitored at } 5 \text {-year intervals; if value deviates more than } \\
10 \% \text {, cut dominant species to reach target. Start and end of cutting period may be defined. }\end{array}$} \\
\hline $\mathrm{N}$ fertilisation & \multicolumn{2}{|c|}{$\mathrm{kgN} \mathrm{ha}^{-1} \mathrm{y}^{-1}$, evenly distributed the whole year } \\
\hline Irrigation & \multicolumn{2}{|c|}{ Bypass water stress in photosynthesis } \\
\hline $\begin{array}{l}\text { Fire/disturbance } \\
\text { suppression }\end{array}$ & \multicolumn{2}{|c|}{ Switch off fire and disturbance } \\
\hline Management change & \multicolumn{2}{|c|}{ Change management type a specific calender year (optionally wait for clearcut) ${ }^{1}$} \\
\hline
\end{tabular}

\subsubsection{Continuous cutting}

When modelling continuous cutting, it is possible to define the same harvest parameters and cutting priority settings as described above for the clearcut case, for two different periods: the first for a specified "regeneration" time following a clearcut, and the second for a "continuous" phase, in which the cutting cycle is repeated indefinitely (Fig. 5c). During the continuous phase, the minimum diameter limit in tree size selection option (3) above can be adapted to low productivity by automatically lowering the diameter limit when the required tree diameters are not available. 
https://doi.org/10.5194/gmd-2020-440

Preprint. Discussion started: 27 January 2021

(c) Author(s) 2021. CC BY 4.0 License.

(a)

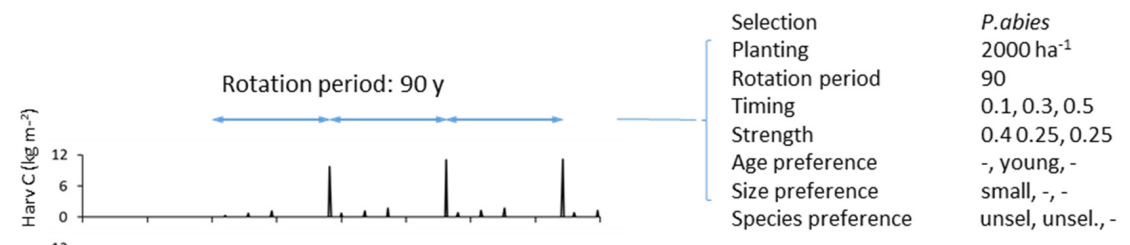

(b)

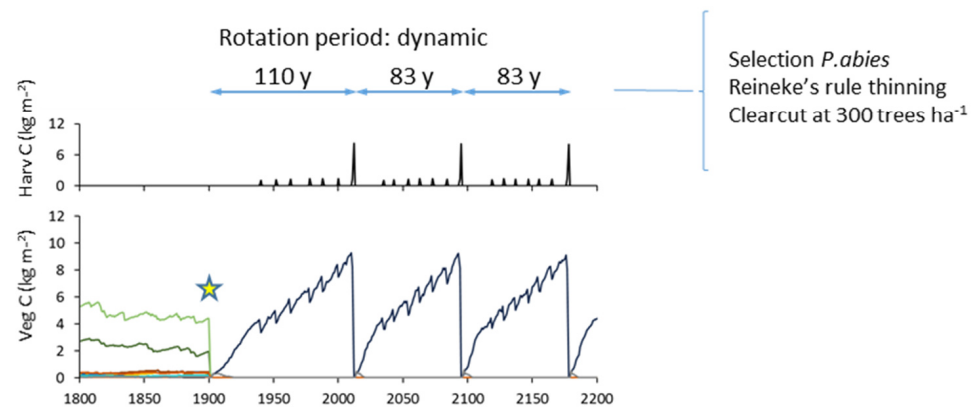

(c)

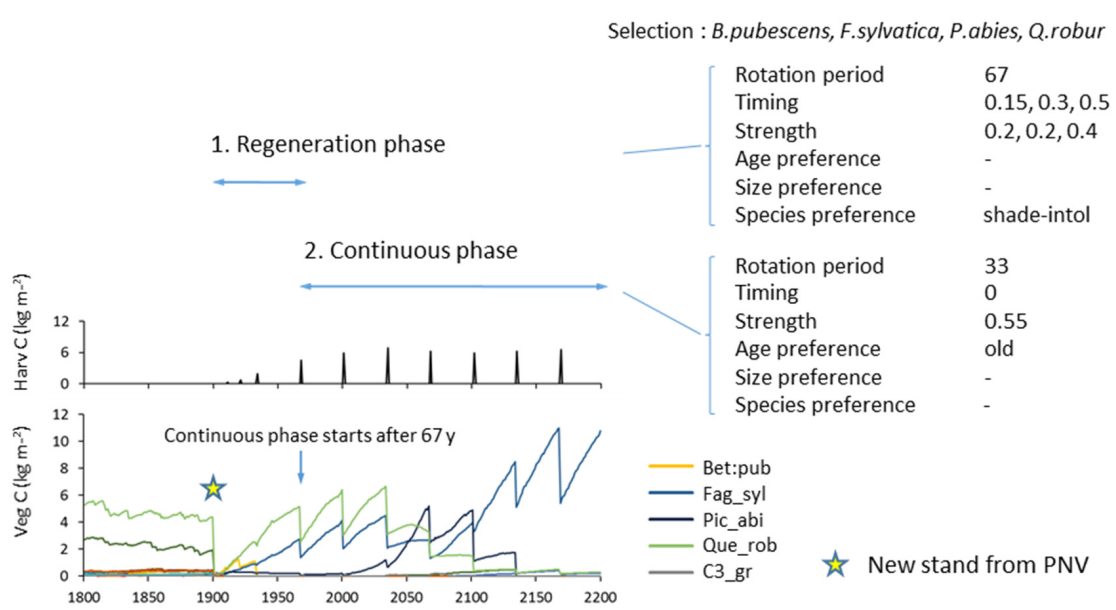

Figure 5. Examples of forest management settings in LPJ-GUESS. Forestry stands were created from clearcut of PNV in 1901. (a)

Detailed clearcut forestry. Spruce monoculture with fixed rotation period and thinning parameters. (b) Automated clearcut forestry. Spruce monoculture with automated thinning and clearcut. (c) Continuous selection/shelterwood cutting. Species selection

B.pubescens, F.sylvatica, P.abies, Q.robur established after clearcut. Later reestablishment of all species allowed. Cutting of shadeintolerant species during a regeneration phase. Contiuous partial harvest of old trees every 33 years allows establishment of young cohorts while suppressing shade-intolerant species. Species/PFT abbreviations: Bet_pen Betula pendula, Fag_syl Fagus sylvatica, Pic_abi Picea abies, Que_rob Quercus robur, C3_gr C3 grass. Location, climate input and species in PNV as in Fig. 2. 


\subsubsection{Automated wood harvest}

As an alternative to specifying the thinning rules in clearcut forestry in detail, a thinning scheme based on Reineke's self-thinning rule may be chosen (Fig. 5b). The implementation follows Bellassen et al. (2010):

$$
\operatorname{dens}_{\max }=\frac{\alpha_{\mathrm{st}}}{D g^{\beta_{s t}}},
$$

where dens $s_{\max }$ is stand maximum density before self-thinning (trees ha ${ }^{-1}$ ), $\alpha_{\text {st }}$ and $\beta_{s t}$ are fixed parameters and $D g$ is the quadratic mean diameter $(\mathrm{m})$,

$$
D g=\sqrt{\frac{\sum_{i} \operatorname{diam}_{i}^{2}}{N}}
$$

where $\operatorname{diam}_{i}$ is the tree diameter $(\mathrm{m})$ of an individual tree and $\mathrm{N}$ the number of sampled trees

$\alpha_{\text {st }}$ and $\beta_{\text {st }}$ were calibrated from $\log$-log plots of $D g$ and tree density, dens, from LPJ-GUESS simulations of monocultures without disturbance or re-establishment, starting from bare ground after clearcut of PNV (Fig. C1):

$$
\log D g=\frac{\log \alpha_{\text {st }}}{\beta_{s t}}-\frac{1}{\beta_{s t}} * \log \text { dens }
$$

To avoid natural tree mortality occurring due to the model's self-thinning functionality, the relative density index, $r d i$, is monitored

$$
r d i=\frac{d e n s}{\text { dens }_{\max }}
$$

and kept close to a target value, $r d i_{\text {target }}$, by cutting when $r d i$ reaches $\left(r d i_{\text {target }}+\delta r d i\right)$ to reach $\left(r d i_{\text {target }}-\delta r d i\right)$, where

$$
\delta r d i=0.05+\left(0.05 * \log \left(\frac{\text { dens }}{\text { dens }_{\text {target }}}\right) / \log \left(\frac{\text { dens }_{\text {init }}}{\text { dens }_{\text {target }}}\right)\right),
$$

where dens $s_{\text {init }}$ is the initial tree density and dens $s_{\text {target }}$ is the density limit for clearcut (se below).

As an alternative to imposing a specified rotation length in clearcut forestry, clearcut may be triggered by stand density when it is

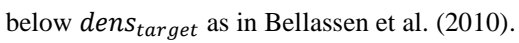

$r d i_{\text {target }}$ and dens $s_{\text {target }}$ were selected and $\alpha_{\text {st }}$ further adjusted to give rotation times around 100 years in the early 2000 s in LPJ-

GUESS simulations (Table A3).

\subsubsection{Nitrogen fertilisation and irrigation}

A specified amount of nitrogen may be applied to the soil every year (Fig. B2). With irrigation enabled, the amount of water required to avoid water stress is calculated and applied every year.

\subsubsection{Management change}

To capture management changes, a new silvicultural treatment of a stand type can be prescribed any specified calender year, changing from one specified management type to another with the next harvest event as an optional trigger (Fig. 6). 


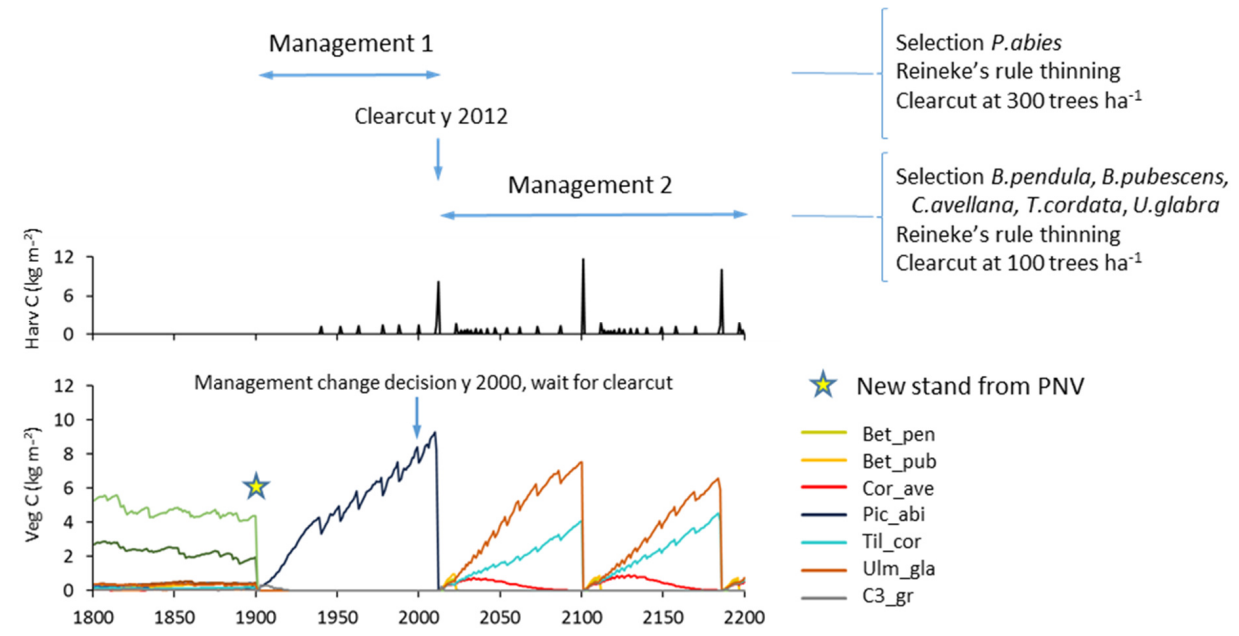

Figure 6. Example of Management change in LPJ-GUESS. Spruce monoculture changed to mixed broadleaved, both with automated thinning and clearcut. Management change is activated after first management has completed by a clearcut event. Location, climate input and species in PNV as in Fig. 2.

\subsection{Demonstration simulation protocol}

To demonstrate the implemented forest management functionality and its effects on simulated stand structure, composition and productivity, we performed demonstration simulations for a representative location (grid cell) in Europe, and across Europe as a whole. PNV stands were modelled using 25 replicate patches and a disturbance return time of 400 years. Managed forest stands contained only one patch except where explicitly stated, disturbance and fire were turned off and mortality was deterministic. In managed forest stands created after clearing the previous vegetation, this setup saves computational time and produces almost identical results compared to using multiple patches and adding the stochastic component to establishment and mortality. The European species as described by Hickler et al. (2012) were used with updated parameters (Table A1-A2) and with the addition of Larix decidua (Scherstjanoi et al., 2014), Populus tremula and Ulmus glabra.

Historic (1901-2015) monthly temperature, radiation and precipitation data at $0.5^{\circ}$ x $0.5^{\circ}$ resolution were taken from the stationbased CRU-NCEP climate data set (Wei et al., 2014) and atmospheric $\mathrm{CO}_{2}$ concentration data from the global carbon project (Le

Quéré et al., 2018). Nitrogen deposition data for 1850-2009 were taken from Lamarque et al. (2011). Simulations began with a 1300-year spinup, to initialise PNV species composition and soil and plant carbon pools. Detrended 1901-1930 climate was recycled and $1901 \mathrm{CO}_{2}$ concentration was prescribed throughout the spinup. Nitrogen deposition data for 1850-1859 were applied before 1860 after which the historic data were used as forcing. After 2015, the 1986-2015 climate data and the $2015 \mathrm{CO}_{2}$ were recycled and after 2009, the 2000-2009 nitrogen deposition data were assumed.

In future climate scenario simulations, monthly temperature, radiation and precipitation data for 1850-2100 were adopted from the general circulation model (GCM) IPSLCM5A-MR (Dufresne et al., 2013) projections from the CMIP5 ensemble (Taylor et al., 2011). Projections forced by the RCP 4.5 and 8.5 future radiative forcing scenarios were used. The raw GCM climate output fields were interpolated to $0.5^{\circ} \mathrm{x} 0.5^{\circ}$ resolution and bias-corrected on a monthly basis against the CRU-NCEP 1961-1990 observational climate, following the approach of Ahlström et al. (2012). Atmospheric $\mathrm{CO}_{2}$ concentration data for 1850-2100 consistent with the CMIP5 GCM forcing were used. During a 1250-year spinup, the detrended 1850-1879 climate was recycled and the $1850 \mathrm{CO}_{2}$ and 
nitrogen deposition data (Lamarque et al., 2011) were used. After 2100, the 2071-2100 detrended climate data were recycled and the $2100 \mathrm{CO}_{2}$ data and the 2090-2099 nitrogen deposition data were used.

In future forest projections, either the historic environmental drivers were recycled after 2015 or future climate, $\mathrm{CO}_{2}$ and nitrogen projections were used to demonstrate model behaviour under a time-span of several forest rotations.

\subsection{Site-level simulations}

A gridcell in southern Sweden $\left(13.75^{\circ} \mathrm{E}, 55.75^{\circ} \mathrm{N}\right)$ was selected for demonstrating forest development under different forest stand histories and initialisation and management strategies. Setup and CRU-NCEP climate was as described in 2.4, except that 3 patches were used in secondary forest stands when illustrating among-patch age structure setup.

\subsection{European simulations}

\subsubsection{Forcing data}

To constrain European secondary forest age and species structure in the model to the actual state of the forests, we used the global forest age dataset GFAD (Poulter et al., 2019; Pugh et al., 2019), describing the $0.5^{\circ} \times 0.5^{\circ}$ gridcell fraction coverage of fourteen 10 -year cohorts of the four forest types needleleaf evergreen (NE), needleleaf deciduous (ND), broadleaf evergreen (BE) and broadleaf deciduous (BD) forest in year 2010. For Europe, the data were based on EFISCEN in the 2000s. European forests (excluding Russia outside of the Kaliningrad oblast, Georgia, Iceland and Cyprus in this study) consisted of 0.6 million $\mathrm{km}^{2}$ oldgrowth forests (> 140 years) and 1.8 million $\mathrm{km}^{2}$ regrowth forests in 2010 according to GFAD, together making up about $43 \%$ of the European land area. This is higher than other estimates (e.g. Forest Europe (2015), 35\%) and is a result of the construction of the GFAD database from MODIS 5.0, with the inclusion of shrubland. In GFAD, regrowth forests are the result of both natural disturbances and human interventions, but since only $0.7 \%$ of European forests are pristine (Sabatini et al., 2018), the whole regrowth forest area was assigned to secondary forest in this study.

The EFI Tree species map describes the spatial distribution (fraction of land area) of 20 tree species groups at 1 x $1 \mathrm{~km}$ resolution (Brus et al., 2011). The map is based on ICP-Forest Level-I plot data combined with National Forest Inventory (NFI) data of 18 countries. In areas with NFI data, spatial interpolation of the plot data was used, whereas in areas without NFI data, statistical relationships between tree species and covariates (soil, biogegraphy and bioindicators) were used (Brus et al., 2011). The EFI Tree species map was aggregated to $0.5^{\circ} \times 0.5^{\circ}$ resolution in this study and was used to further refine the species distribution derived from GFAD.

The structure of European forests in 2010 was reconstructed by using a combination of the the GFAD age database and the EFI Tree species map. For each gridcell, the most common species or species group within the GFAD NE and BD forest types were obtained from the EFI Tree species map and these species groups were then mapped to LPJ-GUESS tree species/species groups (Table C1, Fig. C2). In the multi-species LPJ-GUESS groups, species compete with each other for resources (cf. above, 2.1). BE was mapped to Quercus ilex and ND to Larix decidua, the only available PFTs in the model to represent these two functional tree classes.

\subsubsection{Modelling current and future European managed forests}

Secondary forest stands were created in the model from 1871 to 2010 to obtain the GFAD age (1-140 years) distribution in 2010

and species selections were planted (without climate restrictions for NE and ND stands to bypass establishment temperature limits used in PNV). The oldest forest class in GFAD (>140 years) was modelled as PNV and was not subject to any management. In secondary stands, automated thinning and clearcut (cf. 2.3.2) were implemented using the parameters in Table A3. Thinnings 
started at a stand age of 10 years (young and shrubs/shade-tolerant first) and clearcuts started after year 2010. Clearcuts of stands that passed below the tree density limit before 2011 were distributed over the years 2011-2020. In an alternative simulation with identical stand structure setup, thinning and clearcutting were turned off.

\subsubsection{Calculation of output variables}

Growing stock, net annual increment (NAI) and harvested volume were calculated from vegetation carbon, net ecosystem exchange (NEE) and killed vegetation carbon during harvest by multiplying with expansion factors for each country, ranging from 1.1 to 3.5 (mean 2.7) $\mathrm{m}^{3} \mathrm{tC}^{-1}$, derived from vegetation carbon and growing volumes reported by Forest Europe (2015). Carbon sink (= -NEE) is defined as the difference in the sum of vegetation and soil carbon pools between two consecutive years plus the removed harvested carbon, not taking into account any reductions in wood products and residues following removal from the site. Similarly, NAI is defined as the difference in growing stock volume between two consecutive years plus the removed harvested volume. Harvested carbon is not included in the total carbon pool and includes both wood products and removed wood residues. The forested area in 2010 as defined by GFAD and Forest Europe (2015) was 2.4 and 2.0 million km², respectively, excluding Georgia, Iceland, Cyprus and Malta, but including Kaliningrad oblast and European part of Turkey. The forest area available for wood supply (FAWS), for GFAD defined as the secondary forest area in 2010, was 1.8 and 1.6 million $\mathrm{km}^{2}$ for GFAD and Forest Europe (2015), respectively.

\section{Results}

\subsection{Implications of secondary forest initialisation and land-use history}

320 Secondary forest stand initialisation and land-use history have long-term effects on the development of tree species distribution, productivity and carbon fluxes in the model (Fig. 2). When the age distribution and species composition from spinup is retained in each patch (i.e. cloning PNV), both the warming climate in the 20th century and the prevention of fires and other disturbances result in an increase in tree biomass and a tree species shift from a Q.robur-P.sylvestris-dominated forest landscape to a forest increasingly dominated by the shade-tolerant species P.abies and F.sylvatica in an example forest simulated at a Southern Swedish site (Fig. 2a). Older patches contribute to an early-onset stagnation of the carbon sink. A forest stand created after a clearcut of PNV displays a mixed broad-leaf forest with a late establishment and dominance by P.abies (Fig. 2b\&c). Leaving harvested biomass on site results in an extended litter-induced carbon source (Fig. 2b). When the previous land-use history is grassland, the initial dominance by shade-intolerant species is more pronounced and the slow accumulation of the litter pool results in a stronger and more protracted carbon sink (Fig. 2d\&e). Soil carbon and nitrogen depletion due to intensive harvest of the previous grassland influences productivity, succession of tree species and carbon sink capacity of the secondary forest. Initial tree growth is delayed by several decades, the dominant shade-intolerant species is P.sylvestris rather than B.pubescens and Q.robur competes more successfully than under normal soil nitrogen (Fig. 2e). Also, the long-term carbon sink is larger than in any other option. The big differences in tree species succession and the timing and magnitude of the carbon sink using the different stand creation options illustrate the importance of land-use history for modelling secondary forest stands.

\subsection{Choosing between different model age/species structure and harvest alternatives}

The choice between the different age- and species structure setup options depends on whether competition between species and cohorts within patches is required or not (Fig. 3-4). Also, the desired level of detail of the age structure might decide whether to use a simplified setup or a detailed structure with many separate stands, increasing computation time. Setups using separate stands 
for each species-age combination offer the possibility of reflecting regional distributions based on inventory data, but might not

represent competition correctly e.g. in mixed forests.

Although management changes during the course of a simulation may be prescribed, using detailed, but static, harvest methods would not reflect foresters' choice of gradual adaptation of harvest parameters under changing $\mathrm{CO}_{2} /$ climate conditions in future scenarios. In these cases, the simplified dynamic harvest methods might be a better option (Fig. 5b).

\subsection{European-wide simulations of managed forest}

345 Dominant tree species in managed forests based on the EFI species map differ from PNV simulations in large parts of Europe. In central and eastern Europe, broadleaved species are to a large degree replaced by needleleaved species in managed forests, especially by P.sylvestris, but since old-growth forest is modelled as PNV in this study, the dominance by needleleaves in this region seen in the original EFI data is moderated in the total forest landscape (Fig. C3, C4).

Table 2. Modelled and observed forest vegetation carbon stock in Europe ${ }^{1}$.

\begin{tabular}{|c|c|c|c|c|}
\hline & $\begin{array}{l}\text { LPJ- } \\
\text { GUESS } \\
\text { (this study) }\end{array}$ & Liu et al. $2015^{2}$ & Pan et al. 2011 & Forest Europe \\
\hline \multicolumn{5}{|c|}{ Veg C (Pg) } \\
\hline \multicolumn{5}{|c|}{ Europe $^{3}$} \\
\hline 2000 & $13.8(14.3)$ & 11.1 & 11.8 & 10.2 \\
\hline 2007 & $14.1(14.7)$ & 11.6 & 13 & \\
\hline 2010 & $14.3(15.0)$ & & & 11.8 \\
\hline 2015 & $14.2(15.8)$ & & & 12.5 \\
\hline \multicolumn{5}{|c|}{ EU-28 + Switzerland ${ }^{4}$} \\
\hline 2000 & $11.3(11.7)$ & & & 8.3 \\
\hline 2010 & $11.6(12.2)$ & & & 9.4 \\
\hline 2015 & $11.4(12,9)$ & & & 10.0 \\
\hline \multicolumn{5}{|c|}{$\operatorname{Veg} C\left(\mathrm{~kg} \mathrm{~m}^{-2}\right)$} \\
\hline \multicolumn{5}{|c|}{ Europe $^{3}$} \\
\hline 2000 & $5.5(5.7)$ & 5.5 & 5.9 & 5.3 \\
\hline 2007 & $5.7(5.9)$ & 5.7 & 6.4 & \\
\hline 2010 & $5.7(6.0)$ & & & 5.9 \\
\hline 2015 & $5.7(6.4)$ & & & 6.3 \\
\hline \multicolumn{5}{|c|}{ EU-28 + Switzerland ${ }^{4}$} \\
\hline 2000 & $5.8(6.0)$ & & & 5.3 \\
\hline 2010 & $5.9(6.2)$ & & & 5.9 \\
\hline 2015 & $5.9(6.6)$ & & & 6.2 \\
\hline
\end{tabular}

$\overline{{ }^{1} \text { Values in parentheses are for a simulation without wood harvest in secondary forest. }{ }^{2} \text { AG biomass }}=79 \%$ of total biomass; ${ }^{3}$ Excluding Iceland, Cyprus and Malta. Including Kaliningrad oblast and European part of Turkey in LPJ-GUESS data. ${ }^{4}$ Cyprus and Malta are excluded.

For the European continent, the modelled mean vegetation carbon density $\left(5.7 \mathrm{kgC} \mathrm{m}^{-2}\right)$ and growing stock $\left(156 \mathrm{~m}^{3} \mathrm{ha}^{-1}\right)$ in 2010 and NAI $\left(5.4 \mathrm{~m}^{3} \mathrm{ha}^{-1} \mathrm{y}^{-1}\right)$ in 2001-2010 in a simulation with thinning is close to observations (Tables 2,4). The total carbon pool $\left(24.2-24.3 \mathrm{kgC} \mathrm{m}^{-2}\right)$ and soil/litter pool in 2000-2010 (18.5-18.6 $\left.\mathrm{kgC} \mathrm{m}^{-2}\right)$ is $21-64 \%$ and $34-80 \%$ higher than observations, respectively, while NEE in 2000-2007 (ca. $-0.08 \mathrm{kgC} \mathrm{m}^{-2} \mathrm{y}^{-1}$ ) is $63 \%$ of observed values (Table 3). Fellings including clearcuts of old-growth forests and thinnings in regrowth forests $\left(5.0 \mathrm{~m}^{3} \mathrm{ha}^{-1} \mathrm{y}^{-1}\right)$ and thinnings in regrowth forests only $\left(3.0 \mathrm{~m}^{3} \mathrm{ha}^{-1} \mathrm{y}^{-1}\right)$ in 
https://doi.org/10.5194/gmd-2020-440

Preprint. Discussion started: 27 January 2021

(c) Author(s) 2021. CC BY 4.0 License.

Table 3. Modelled and observed total carbon stock, soil/litter carbon and net echosystem exchange (NEE) in European forests ${ }^{1}$.

\begin{tabular}{|c|c|c|c|}
\hline & LPJ-GUESS & Pan et al. 2011 & Forest Europe $^{2}$ \\
\hline \multicolumn{4}{|c|}{ Total C stock (Pg) } \\
\hline \multicolumn{4}{|l|}{ Europe } \\
\hline 2000 & $60.3(62.3)$ & 39.3 & \\
\hline 2007 & $60.4(62.8)$ & 40.9 & \\
\hline $2010^{2}$ & $60.5(63.1)$ & & 29.3 \\
\hline \multicolumn{4}{|c|}{ EU-28 + Switzerland } \\
\hline $2010^{2}$ & $48.6(50.7)$ & & 25.5 \\
\hline \multicolumn{4}{|c|}{ Total C stock $\left(\mathrm{kg} \mathrm{m}^{-2}\right)$} \\
\hline \multicolumn{4}{|l|}{ Europe } \\
\hline 2000 & $24.2(25.0)$ & 19.7 & \\
\hline 2007 & $24.2(25.2)$ & 20.0 & \\
\hline $2010^{2}$ & $24.3(25.6)$ & & 14.8 \\
\hline \multicolumn{4}{|c|}{ EU-28 + Switzerland } \\
\hline $2010^{2}$ & $24.9(26.1)$ & & 15.9 \\
\hline \multicolumn{4}{|c|}{ Soil+Litter C stock $(\mathbf{P g})$} \\
\hline \multicolumn{4}{|c|}{ Europe } \\
\hline 2000 & $46.5(48.0)$ & 27.6 & \\
\hline 2007 & $46.3(48.1)$ & 28.0 & \\
\hline $2010^{2}$ & $46.2(48.2)$ & & 17.5 \\
\hline \multicolumn{4}{|c|}{ EU-28+ Switzerland } \\
\hline $2010^{2}$ & $37.0(38.6)$ & & 16.1 \\
\hline \multicolumn{4}{|c|}{ Soil+Litter $\mathrm{C}\left(\mathrm{kg} \mathrm{m}^{-2}\right)$} \\
\hline \multicolumn{4}{|c|}{ Europe } \\
\hline 2000 & $18.6(19.2)$ & 13.9 & \\
\hline 2007 & $18.5(19.3)$ & 13.7 & \\
\hline $2010^{2}$ & $18.5(19.3)$ & & 10.3 \\
\hline \multicolumn{4}{|c|}{ EU-28 + Switzerland } \\
\hline $2010^{2}$ & $19.0(19.8)$ & & 10.8 \\
\hline \multicolumn{4}{|c|}{ NEE $(\mathrm{PgC} / \mathrm{y})$} \\
\hline \multicolumn{4}{|c|}{ Europe } \\
\hline $1990-1999$ & $-0.188(-0.141)$ & -0.30 & \\
\hline $2000-2007$ & $-0.212(-0.153)$ & -0.27 & \\
\hline \multicolumn{4}{|c|}{ NEE $\left(\operatorname{kgC~m}^{-2} y^{-1}\right)$} \\
\hline \multicolumn{4}{|l|}{ Europe } \\
\hline 1990-1999 & $-0.075(-0.056)$ & -0.154 & \\
\hline $2000-2007$ & $-0.085(-0.061)$ & -0.134 & \\
\hline
\end{tabular}


Table 4. Modelled and observed growing stock (GS) in European forests in 2010 and Net annual increase (NAI) and fellings in forests available for wood supply (FAWS) in Europe for 2001-2010 .

\begin{tabular}{|c|c|c|}
\hline & LPJ-GUESS ${ }^{2}$ & Forest Europe ${ }^{3}$ \\
\hline \multicolumn{3}{|l|}{ GS (million $\mathbf{m}^{3}$ ) } \\
\hline Europe & 38136 (39859) & 31225 \\
\hline EU-28 + Switzerland & 31794 (33385) & 25357 \\
\hline \multicolumn{3}{|l|}{ GS $\left(\mathrm{m}^{3} \mathrm{ha}^{-1}\right)$} \\
\hline Europe & $156(163)$ & 157 \\
\hline EU-28 + Switzerland & $163(171)$ & 158 \\
\hline \multicolumn{3}{|l|}{ NAI (million $\left.\mathbf{m}^{3} \mathbf{y}^{-1}\right)$} \\
\hline Europe & $966(484)$ & 841 \\
\hline EU-28 + Switzerland & $781(401)$ & 732 \\
\hline \multicolumn{3}{|l|}{ NAI $\left(\mathbf{m}^{3} h^{-1} \mathbf{y}^{-1}\right)$} \\
\hline Europe & $5.4(2.7)$ & 5.1 \\
\hline EU-28 + Switzerland & $5.4(2.8)$ & 5.4 \\
\hline \multicolumn{3}{|l|}{ Fellings (million $\left.\mathbf{m}^{3} \mathbf{y}^{-1}\right)$} \\
\hline Europe & $896(380)$ & 562 \\
\hline EU-28 + Switzerland & $746(333)$ & 527 \\
\hline \multicolumn{3}{|l|}{ Fellings $\left(\mathrm{m}^{3} \mathbf{h a}^{-1} \mathbf{y}^{-1}\right)$} \\
\hline Europe & $5.0(2.0)$ & 3.4 \\
\hline EU-28+ Switzerland & $5.2(2.3)$ & 3.9 \\
\hline
\end{tabular}

${ }^{1}$ Values in parentheses are for a simulation without wood harvest in regrowth forest. As FAWS, secondary forest in 2010 is considered in LPJ-GUESS simulations. ${ }^{2}$ Mean of the years 2001-2010, AG biomass $=80 \%$ of total biomass for Europe, using AG fractions from Forest Europe data for EU-28+Switzerland, values in brackets are for a simulation without wood harvest in regrowth forest. ${ }^{3}$ Mean of the years 2000, 2005 and 2010, or for the avalable data for these years, except for Greece (1990 value). Europe area definition as in Table 2.

Modelled vegetation carbon, total carbon pool, growing stock, NAI and fellings for individual European countries show varying levels of agreement with observations, with the best fit for vegetation carbon and growing stock ( $\mathrm{r} 2=0.49$ and 0.72 , respectively) and the least for NAI (r2=0.06) (Fig. 7-9, Fig. D1-D5). Modelled mean European total thinning fractions of produced wood over the whole rotation period in stands clearcut in 2011-2020 were 0.4 for BD and 0.5 for NE (not shown). Total thinning fractions of NAI for individual countries in 2001-2010 were between 0.35 and 0.6, with a total European mean of 0.53 (Fig. D4-D5). The corresponding annual thinning fractions of growing stocks were $0.8 \%$ to $3.3 \%$, with a mean of $1.9 \%$ (Fig. D3, D5). 
https://doi.org/10.5194/gmd-2020-440

Preprint. Discussion started: 27 January 2021

(C) Author(s) 2021. CC BY 4.0 License.

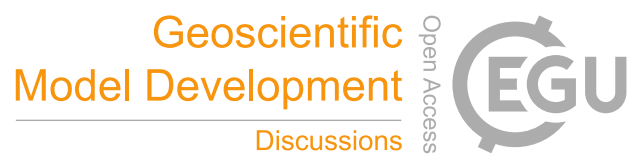

(a)

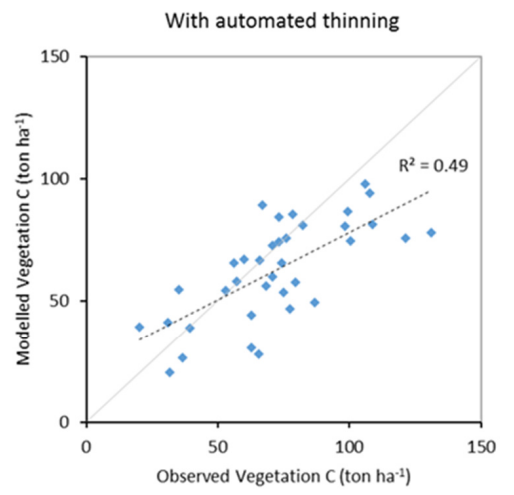

(c)

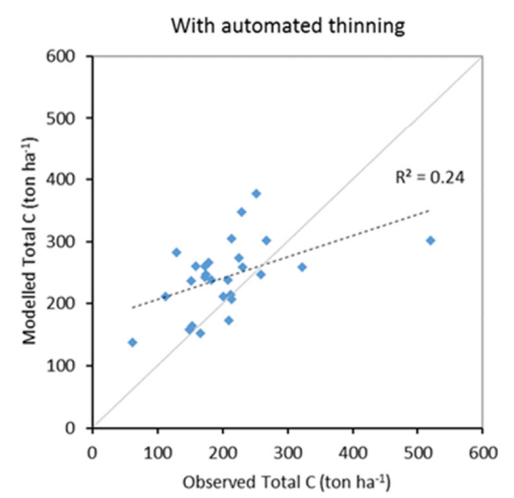

(b)

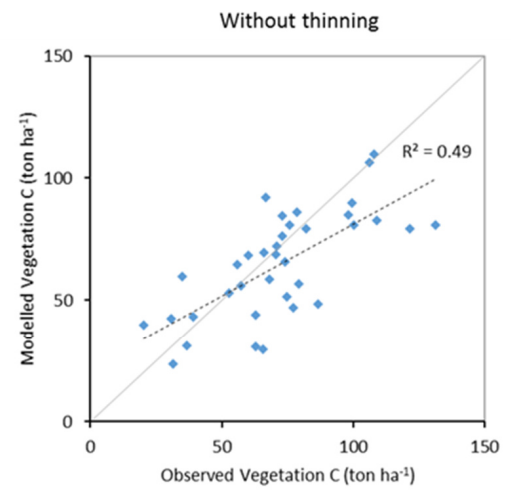

(d)

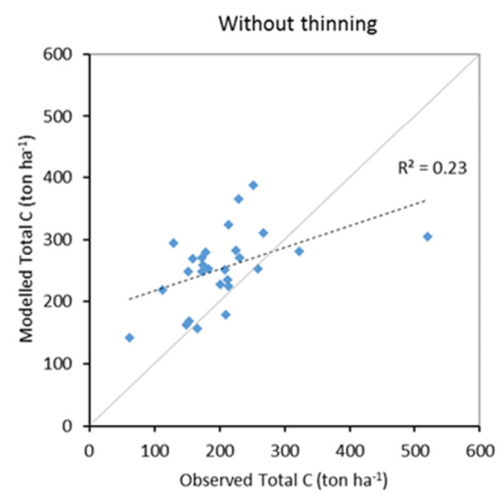

Figure 7. Modelled and observed (Forest Europe 2015) values for individual countries in 2010. Vegetation carbon: (a) Simulation with automated thinning. (b) Simulation without thinning. Total carbon pool: (c) Simulation with automated thinning. (d) Simulation without thinning. 
https://doi.org/10.5194/gmd-2020-440

Preprint. Discussion started: 27 January 2021

(C) Author(s) 2021. CC BY 4.0 License.

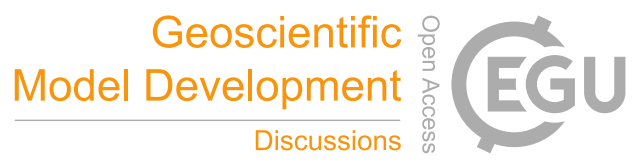

(a)

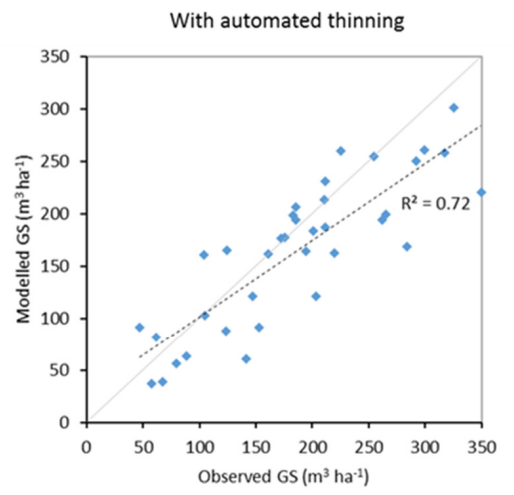

(c)

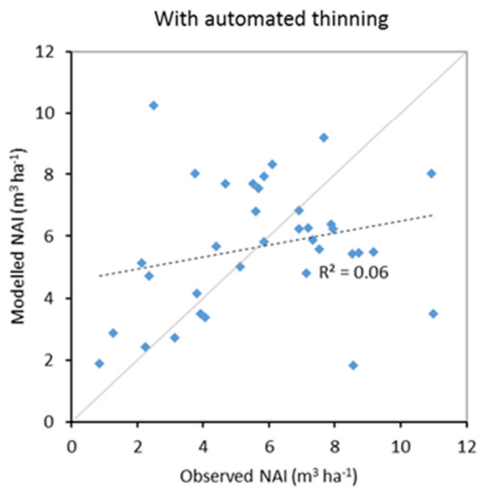

(b)

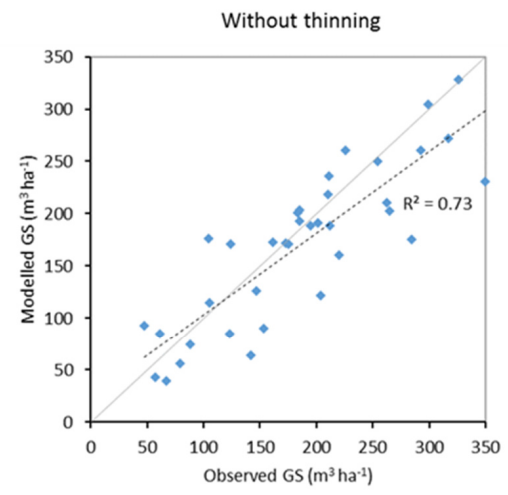

(c)

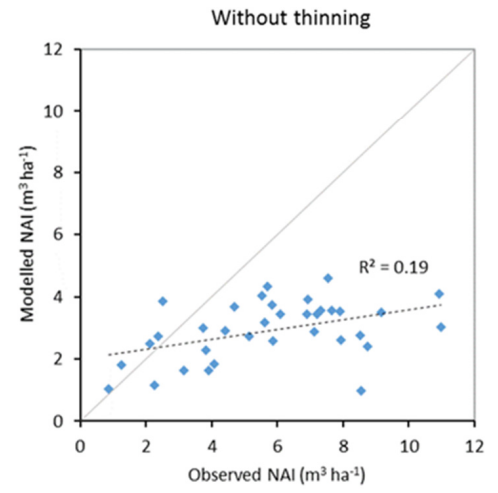

Figure 8. Modelled and observed (Forest Europe 2015) values for individual countries. Growing stock (GS) in 2010: (a) simulation with automated thinning. (b) simulation without thinning. Net annual increase (NAI) in 2001-2010: (c) simulation with automated thinning. (d) simulation without thinning. 
(a)

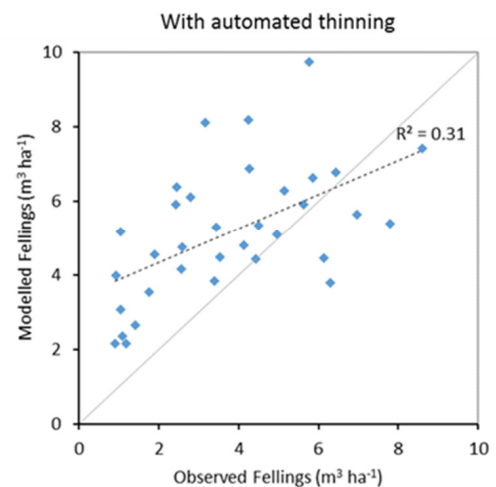

(b)

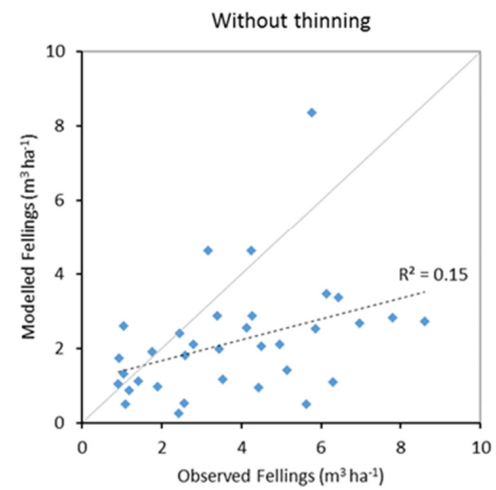

Figure 9. Modelled and observed (Forest Europe 2015) yearly fellings for individual countries in 2001-2010. (a) Simulation with automated thinning. (b) Simulation without thinning (clearcuts at creation of secondary forest).

Carbon pools and fluxes were partitioned into old-growth and regrowth forest components (modelled as PNV and secondary forest stands, respectively) (Fig. 10, Tables 5-6). Modelled European old-growth and regrowth forests have about equally sized vegetation carbon pools in 2000 (about $7 \mathrm{PgC}$ each), but with a downward trend for old-growth forests in 2001-2010 because of a reduction in area. The vegetation carbon density in old-growth forests, increasing from 8.5 to $9.2 \mathrm{kgC} \mathrm{m}^{-2}$ between 2000 and 2015 , is about twice the value in regrowth forests, increasing from 4.0 to $4.5 \mathrm{kgC} \mathrm{m}^{-2}$ between 2000 and 2015 . This vegetation carbon difference is reflected in the difference between old-growth and regrowth forest total carbon pool density (ca. 27 and $23 \mathrm{kgC} \mathrm{m}^{-2}$, respectively), while the soil/litter carbon is slightly higher $(1.5 \%)$ in regrowth forests (Table 5). The modelled forest carbon sink (= -NEE) (2001-2010: $\left.0.23 \mathrm{PgC}^{-1}\right)$ is dominated by regrowth forests $\left(0.20 \mathrm{PgC}^{-1}\right.$ or $\left.0.12 \mathrm{kgC} \mathrm{m}^{-2} \mathrm{y}^{-1}\right)$, compared to $0.03 \mathrm{PgC}^{-1}$ or 0.04 $\mathrm{kgC} \mathrm{m} \mathrm{y}^{-1}$ in old-growth forests (Table 6).

For the European continent, including thinning in the simulation reduced total forest vegetation carbon, soil/litter carbon, total carbon pool and growing stock in 2010 by 3-5 \%, increased the magnitude of NEE in 2000-2007 by $39 \%$ and increased NAI in 2001-2010 by $100 \%$ compared to a simulation without thinning (Fig. 11-12, Tables 2-4). In regrowth forests, including thinning reduced vegetation carbon by 6-7 \%, soil/litter carbon and the total carbon pool by 5-6\% in 2000-2010 and increased the magnitude of NEE in 1991-2010 by $41 \%$ (Tables 5-6). The average thinning rate on regrowth forest land was $1.9 \%$ of wood biomass/year in 2001-2010. Including thinning generally improved the match of simulations with observed data. The increased regrowth forest carbon sink seen in a simulation with thinning $\left(0.12 \mathrm{kgC} \mathrm{m}^{-2} \mathrm{y}^{-1}\right)$ (Fig. 10) is correlated with a strong reduction of natural mortality (-80\% in 1991-2015) in regrowth forest stands, induced by thinning and, after 2010, rejuvenation of regrowth forest stands 
https://doi.org/10.5194/gmd-2020-440

Preprint. Discussion started: 27 January 2021

(C) Author(s) 2021. CC BY 4.0 License.

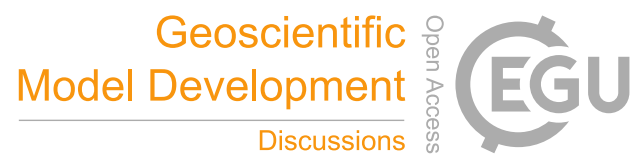

(a)

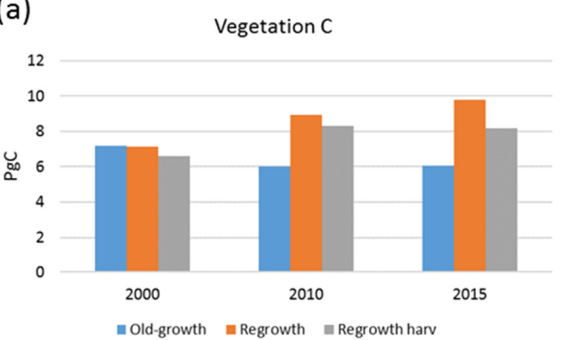

(b)
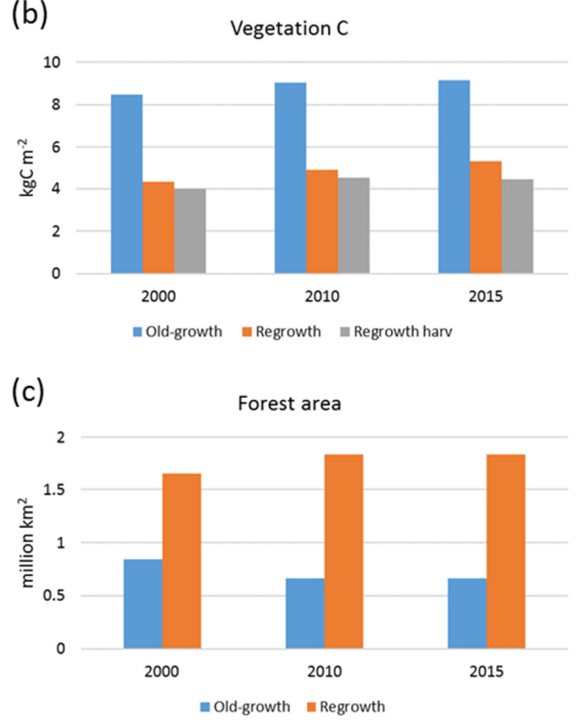
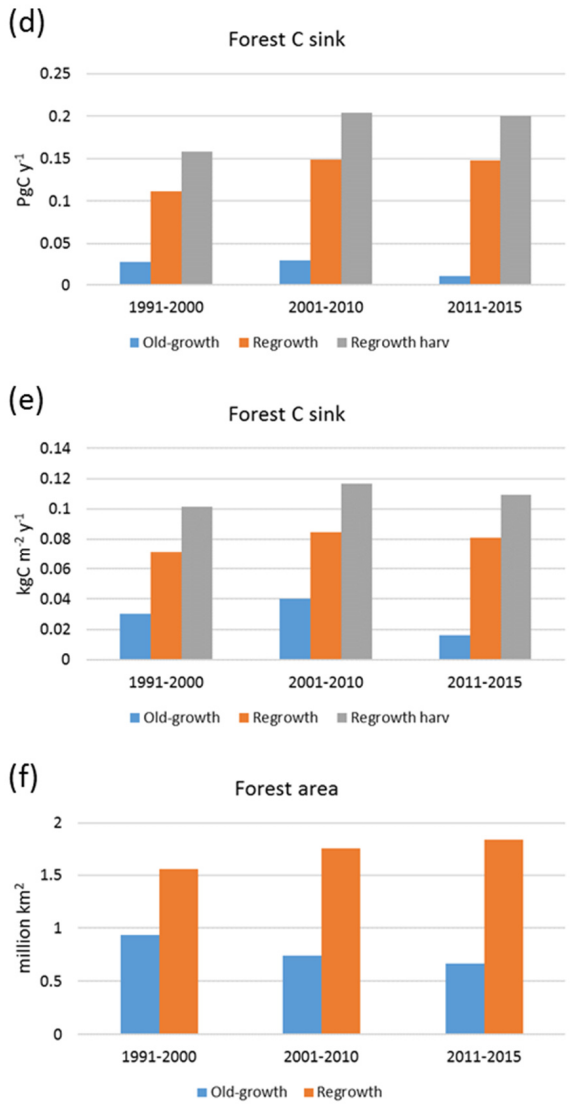

Figure 10. Modelled European forest vegetation carbon for 2000, 2010 and 2015 and carbon sink (= -NEE) for the periods 1991-2000, 2001-2010 and 2011-2015, separated into old-growth and regrowth forest (with and without wood harvest in regrowth forest). (a) Vegetation carbon. (b) Vegetation carbon per area. (c) Old-growth and regrowth forest area in 2000,2010 and 2015. (d) Total forest carbon sink. (e) Mean forest carbon sink per area. (f) Old-growth and regrowth forest area in 1991-2000, 2001-2010 and 2011-2015. 
https://doi.org/10.5194/gmd-2020-440

Preprint. Discussion started: 27 January 2021

(c) Author(s) 2021. CC BY 4.0 License.

Table 5. Vegetation carbon and total carbon stock in European forests ${ }^{1}$, separated into regrowth and old-growth forest.

\begin{tabular}{|c|c|c|c|}
\hline & Total forest & Regrowth forest & Old-growth forest \\
\hline \multicolumn{4}{|c|}{ Veg C (Pg) } \\
\hline 2000 & $13.8(14.3)$ & $6.6(7.1)$ & 7.2 \\
\hline 2007 & $14.1(14.7)$ & $7.8(8.3)$ & 6.4 \\
\hline 2010 & $14.3(15.0)$ & $8.3(9.0)$ & 6.0 \\
\hline 2015 & $14.2(15.8)$ & $8.2(9.8)$ & 6.1 \\
\hline \multicolumn{4}{|c|}{$\operatorname{Veg} \mathbf{C}\left(\mathbf{k g ~ m}^{-2}\right)$} \\
\hline 2000 & $5.5(5.7)$ & $4.0(4.3)$ & 8.5 \\
\hline 2007 & $5.7(5.9)$ & $4.4(4.7)$ & 8.8 \\
\hline 2010 & $5.7(6.0)$ & $4.5(4.9)$ & 9.1 \\
\hline 2015 & $5.7(6.4)$ & $4.5(5.3)$ & 9.2 \\
\hline \multicolumn{4}{|c|}{ Soil+Litter C (Pg) } \\
\hline 2000 & $46.5(47.6)$ & $30.9(32.4)$ & 15.6 \\
\hline 2007 & $46.3(48.1)$ & $33.1(34.9)$ & 13.2 \\
\hline 2010 & $46.2(48.2)$ & $34.0(36.0)$ & 12.2 \\
\hline 2015 & $46.1(48.1)$ & $34.0(35.9)$ & 12.2 \\
\hline \multicolumn{4}{|c|}{ Soil+Litter $\left(\mathrm{kg} \mathrm{m}^{-2}\right)$} \\
\hline 2000 & $18.6(19.2)$ & $18.8(19.6)$ & 18.4 \\
\hline 2007 & $18.5(19.3)$ & $18.6(19.6)$ & 18.3 \\
\hline 2010 & $18.5(19.3)$ & $18.6(19.7)$ & 18.3 \\
\hline 2015 & $18.5(19.3)$ & $18.6(19.6)$ & 18.3 \\
\hline \multicolumn{4}{|c|}{ Total C stock (Pg) } \\
\hline 2000 & $60.3(62.3)$ & $37.5(39.5)$ & 22.7 \\
\hline 2007 & $60.4(62.8)$ & $40.9(43.2)$ & 19.5 \\
\hline 2010 & $60.5(63.1)$ & $42.3(45.0)$ & 18.2 \\
\hline 2015 & $60.6(64.0)$ & $42.1(45.7)$ & 18.2 \\
\hline \multicolumn{4}{|c|}{ Total C stock $\left(\mathrm{kg} \mathrm{m}^{-2}\right)$} \\
\hline 2000 & $24.2(25.0)$ & $22.8(24.0)$ & 26.9 \\
\hline 2007 & $24.2(25.2)$ & $23.0(24.3)$ & 27.2 \\
\hline 2010 & $24.3(25.3)$ & $23.1(24.6)$ & 27.4 \\
\hline 2015 & $24.3(25.6)$ & $23.0(25.0)$ & 27.5 \\
\hline
\end{tabular}

${ }^{1}$ Values in parentheses are for a simulation without wood harvest in regrowth forest. Harvest products were not included in the calculations of total carbon. Total Europe area definition as in Table 2.

445 
https://doi.org/10.5194/gmd-2020-440

Preprint. Discussion started: 27 January 2021

(c) Author(s) 2021. CC BY 4.0 License.

Table 6. Net echosystem exchange (NEE), harvested carbon and natural mortality in European forests ${ }^{1}$, separated into regrowth and old-growth forest.

\begin{tabular}{|c|c|c|c|}
\hline & Total forest & Regrowth forest & Old-growth forest \\
\hline \multicolumn{4}{|c|}{$\operatorname{NEE}\left(\operatorname{PgC} y^{-1}\right)$} \\
\hline $1991-2000$ & $-0.187(-0.140)$ & $-0.158(-0.111)$ & -0.028 \\
\hline $2000-2007$ & $-0.212(-0.153)$ & $-0.188(-0.129)$ & -0.024 \\
\hline $2001-2010$ & $-0.234(-0.178)$ & $-0.204(-0.148)$ & -0.030 \\
\hline $2011-2015$ & $-0.211(-0.159)$ & $-0.200(-0.148)$ & -0.011 \\
\hline \multicolumn{4}{|c|}{$\operatorname{NEE}\left(\mathrm{kgC} \mathrm{m}^{-2} \mathrm{y}^{-1}\right)$} \\
\hline $1991-2000$ & $-0.075(-0.056)$ & $-0.106(-0.072)$ & -0.030 \\
\hline $2000-2007$ & $-0.085(-0.061)$ & $-0.110(-0.075)$ & -0.031 \\
\hline $2001-2010$ & $-0.094(-0.071)$ & $-0.117(-0.085)$ & -0.040 \\
\hline $2011-2015$ & $-0.085(-0.064)$ & $-0.109(-0.081)$ & -0.016 \\
\hline \multicolumn{4}{|c|}{ Harvest $\left(\operatorname{PgC~y^{-1})}\right.$} \\
\hline $1991-2000$ & $0.196(0.102)$ & $0.094(0)$ & 0.102 \\
\hline $2001-2010$ & $0.210(0.093)$ & $0.117(0)$ & 0.093 \\
\hline $2011-2015$ & $0.241(0)$ & $0.241(0)$ & 0 \\
\hline \multicolumn{4}{|c|}{ Harvest $\left(\mathrm{kgC} \mathrm{m}^{-2} \mathrm{y}^{-1}\right)$} \\
\hline $1991-2000$ & $0.079(0.041)$ & $0.061(0)$ & 0.109 \\
\hline $2001-2010$ & $0.084(0.037)$ & $0.067(0)$ & 0.125 \\
\hline $2011-2015$ & $0.097(0)$ & $0.132(0)$ & 0 \\
\hline \multicolumn{4}{|c|}{ Mortality $\left(\operatorname{PgC~y}^{-1}\right)$} \\
\hline $1991-2000$ & $0.104(0.201)$ & $0.025(0.123)$ & 0.079 \\
\hline $2001-2010$ & $0.099(0.227)$ & $0.032(0.159)$ & 0.067 \\
\hline $2011-2015$ & $0.100(0.240)$ & $0.035(0.176)$ & 0.064 \\
\hline \multicolumn{4}{|c|}{ Mortality $\left(\mathrm{kgC} \mathrm{m}^{-2} \mathrm{y}^{-1}\right)$} \\
\hline $1991-2000$ & $0.042(0.081)$ & $0.016(0.079)$ & 0.084 \\
\hline $2001-2010$ & $0.040(0.091)$ & $0.018(0.091)$ & 0.090 \\
\hline $2011-2015$ & $0.040(0.096)$ & $0.019(0.096)$ & 0.096 \\
\hline
\end{tabular}

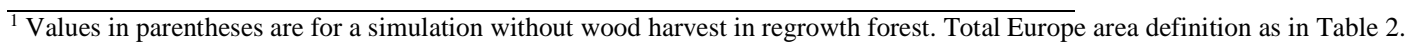


https://doi.org/10.5194/gmd-2020-440

Preprint. Discussion started: 27 January 2021

(c) Author(s) 2021. CC BY 4.0 License.

(a)

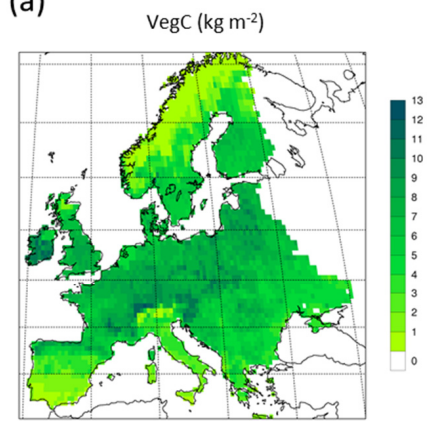

(b)

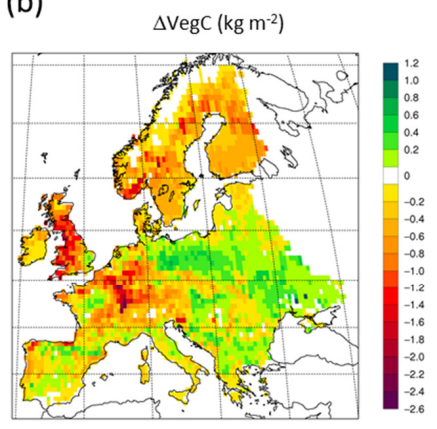

(c)

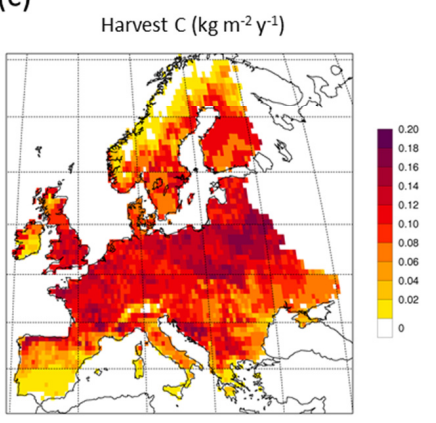

Figure 11. Simulated forest (a) vegetation carbon 2010 in a simulation with thinning, (b) vegetation carbon 2010 difference between simulations with and without wood harvest in regrowth forest. (c) Mean 2001-2010 harvested carbon during thinning on secondary forest. 
(a)

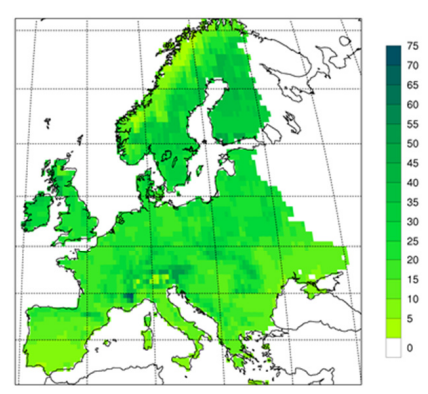

(c)

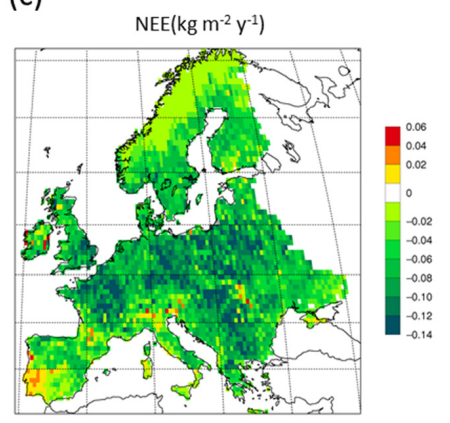

(b)

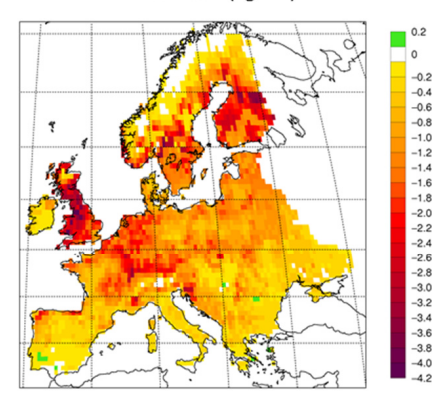

(d)

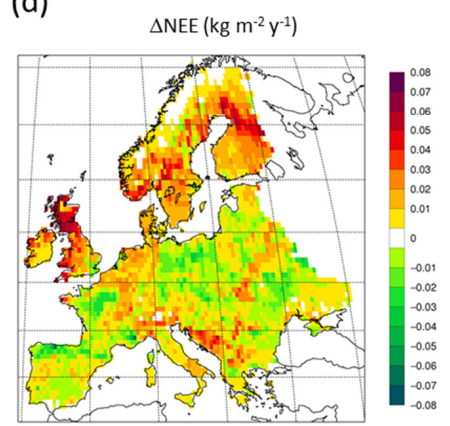

Figure 12. Simulated forest (a) total carbon pool 2010 in a simulation with thinning, (b) total carbon pool 2010 difference between simulations with and without wood harvest in regrowth forest, (c) Mean 2001-2010 NEE in a simulation with thinning, (d) Mean 20012010 NEE difference between simulations with and without thinning.

\subsection{Robustness of automated harvest methods under future climates}

To demonstrate the automated harvest methods, in which thinning intensity and rotation times are adjusted to maintain standing stock when stand productivity changes in response to forcing conditions, we used $\mathrm{CO}_{2} /$ climate projections in extended simulations with an otherwise identical setup as in the European-wide historic simulations. A significant modelled increase in NAI is accompanied by shorter rotation periods (Fig. D8), while a stable vegetation pool in managed forest is maintained (Fig. D9). The mean thinning fraction of the total harvest over the rotation for NE and BD stands increased over the the 21st and 22nd centuries from 0.50 to 0.53 and 0.40 to 0.46 , respectively, for both the RCP4.5 and RCP8.5 simulations (not shown).

\section{Discussion}

LPJ-GUESS representations of unmanaged forest have previously been compared favourably with observed forest vegetation succession, growth, stand structure, biomass and regrowth timescales (Smith et al., 2001; Smith et al., 2014, Pugh et al., 2019) and land use and land-cover change (LULCC) functionality has been included in the model since version 4.0 (Lindeskog et al., 2013).

In a recent global study that used the model to analyse the carbon stocks of old-growth and regrowth forests (modelled as primary and secondary forest stands, respectively), without wood harvest in regrowth stands (Pugh et al., 2019), the total forest carbon sink 
was found to be about $50 \%$ of values reported by Pan et al. (2011). The absence of wood harvest has been identified as an important factor for under-estimating carbon sinks in vegetation models (Zaehle et al., 2006; Ciais et al., 2008). In an effort to improve the ability to simulate carbon pools and fluxes on managed land, we here introduce new forest management options into LPJ-GUESS $\mathrm{v} 4.0$ and provide a comprehensive description of forest initialisation and wood harvest alternatives. The initialisation and harvest alternatives used are constrained by the available forest inventory data and harvest information. Ideally, both age and species structure as well as land-use history and currrent wood harvest strategy should be taken into account, but this is not always possible for simulations with a large spatial extent because of limited data availability. To demonstrate a possible workaround, we used an automated thinning and clearcut alternative to represent European forests, initialised on the basis of inventory-based age- and species data, but without wood harvest- or LULCC data input.

The modelled mean vegetation carbon density in European forests in 2000-2010 is close to observations from several published sources (Pan et al., 2011; Liu et al., 2015; FOREST EUROPE, 2015). Including thinning in the simulation has a rather small impact on vegetation carbon $(<5 \%)$, but after clearcutting starts in regrowth stands after 2010, simulations with and without harvest in regrowth stands diverge strongly (Fig. D7). Also the modelled mean European growing stock is close to observations. Modelled carbon sink density (= -NEE) for European forests in simulations without thinning in the present study is about $46 \%$ of the 2000 2007 value reported by Pan et al. (2011). This is similar to the global carbon sink value for a simulation with a similar setup without thinning, which is $49 \%$ of the global value from the Pan et al. study. The difference in modelled carbon sink in 2001-2010 between old-growth forest $\left(0.04 \mathrm{kgC} \mathrm{m}^{-2} \mathrm{y}^{-1}\right)$ and regrowth forest without thinning $\left(0.085 \mathrm{kgC} \mathrm{m}^{-2} \mathrm{y}^{-1}\right)$, is similar to the difference reported for global old-growth and regrowth forests by Pugh et al. (2019). Adding thinning to the European forest setup increases the carbon sink, by $39 \%$ for the total forest area and by $46 \%$ for the regrowth forest area, reaching $63 \%$ and $82 \%$ of the reported Pan et al. value, respectively. Thinning reduces natural mortality due to relaxed competition between trees, and since a large part of harvested biomass is removed from forest stands, litter input to the soil, and the resulting heterotrophic respiration, is also reduced (Fig. D6D7), increasing the carbon sink.

Details in the simplified European setup might explain the remainder of the "missing" carbon sink, relative to reported values. One cause is that old-growth forests are represented by unmanaged PNV (with a much lower carbon sink, cf. Table 6) in this study (as in Pugh et al. (2019)), which is most likely inappropriate for Europe. Including wood harvest in old-growth forests would be expected to increase the carbon sink. Wildfires also contribute to a lower carbon sink in modelled PNV. A further likely cause of the discrepancy between the modelled and reported carbon balance is that secondary forests are created from PNV stands, without taking land-use history into account. Reforestation of cropland, which generally has a much lower soil carbon content than forests in Europe (Guo et al., 2002), has a higher carbon storage potential than clearing of existing forests. Also, soils of existing European forests have probably been depleted of carbon historically because of higher harvest rates, fuel-wood collection and litter raking (Ciais et al., 2008; McGrath et al., 2015). Higher initial soil carbon pools will increase the release of $\mathrm{CO}_{2}$ in regrowth forests, especially under rising temperatures. Alternative methods to initialise secondary forests (fate of cleared wood, land-use history) have large implications for simulated carbon pools and fluxes as seen in the example Swedish site in this study, e.g. a mean carbon sink over 150 years spanning from 0.078 to $0.188 \mathrm{kgC} \mathrm{m}^{-2} \mathrm{y}^{-1}$ (Fig. 2). This has also been shown at the global scale (Pugh et al., 2019). The high value of modelled European soil carbon density in 2000-2010 (34-80\% higher than observations) supports the possibility that the lack of consideration of land-use and land-cover change history is a main source of the missing carbon sink in this study. The similarity of the modelled mean NAI of European forests in a simulation with thinning to observed values (a 100 $\%$ increase compared to a simulation without thinning), also suggests that the missing carbon sink component could be found in heterotrophic respiration, not in vegetation productivity. 
Our simulation results using LPJ-GUESS are consistent with results from the ORCHIDEE DVM, which was applied with the same automated thinning method (Bellassen et al., 2010). The ORCHIDEE simulation with automated thinning, compared to a simulation without thinning, gave a similar modest vegetation reduction $(7 \%)$, thinning fraction $(0.55)$, reduced heterotrophic respiration (ca. $20 \%$ ) and carbon sink increase (67\%). The forest NPP reduction over time in ORCHIDEE simulations (ca. $10 \%$ ) is also seen in the average value for unharvested regrowth forests in European simulations with LPJ-GUESS, while in simulations with clearcuts in regrowth forests, a balance between stands with different age is seen after clearcut starts in 2011 (Fig. D7b). The decline of NPP directly after thinnings in ORCHIDEE is not included in this version of LPJ-GUESS, but both models display a short-lived increase in heterotrophic respiration after thinnings (not shown). The recovery time after a clearcut (when the stand turns into a carbon sink) is 6 years in the example south Swedish site with a standard harvest removal, but 18 years if the harvested biomass is left on site (Fig. 2). This is similar to the ORCHIDEE results with a stand recovery time of 10-20 years after a clearcut. A similar recovery time, 7-11 years, after clearcuts has been documented by $\mathrm{CO}_{2}$ flux measurements in Sweden (Lindroth et al., 2009).

The automated thinning/clearcut modelling strategy applied in the model in the present study is intended as an example for demonstrating the new forest management capabilities and an improvement on the age-structure setup of Pugh et al. (2019) and does not include all available possibilities in the model. In addition to the shortcomings in the setup already noted concerning landuse history, many central European forests are managed by continuous wood harvest and not by clearcutting and also consist of species mixes. Estimating the effect of such different wood harvest strategies and monoculture/mixed-species alternatives on carbon stocks and fluxes is now possible and will be done in a further study. The self-thinning and tree density-based harvest method is less successful in the northernmost and southernmost parts of Europe, where productivity is strongly limited by temperature and precipitation, respectively, and the self-thinning relationship between biomass and tree density is weaker. The poor productivity of forests in the Mediterranean probably reflects a requirement for a revision of the parameterisation of tree species to better reflect Mediterranean managed forests or possibly the introduction of tree species that are not currently represented in the model (Fig. D8). While the model shows a good fit of mean values for Europe's vegetation carbon and productivity, the correlation between modelled results and observations for the individual countries show a large spread with no simple pattern for the deviations (Fig. D1-D5). However, it is obvious that countries in the Balkans, except Albania and Greece, have modelled thinning fractions higher than the reported total harvest fractions. These countries also show a worse fit to observed NAI values in a simulation with thinning compared to a simulation without thinning. In any case, including thinning in simulations improves the fit to observed national NAI values in most other countries.

New forest management functionallity in LPJ-GUESS includes the most important requirements for the improvment of modelling carbon pools and fluxes as well as the development of forest stands under future climates, but a few important additions will be desirable to include in the future. These include e.g. automated continuous wood harvesting and coppice management. For a good representation of coppicing, the model should also be improved to include plant carbohydrate storage. For better representations of European forests, land-use history, including litter raking, should be included in the setup to generate more realistic soil carbon pools, using functionality already available in the model. 
Appendix A: Supplementary model parameterisation tables.

Table A1 Pft parameters used in this study. Values in bold cursive text are updated compared to Hickler et al (2012).

\begin{tabular}{|c|c|c|c|c|c|c|c|c|}
\hline Species/PFT & Phenology & $\begin{array}{l}\text { Geographic } \\
\text { range }^{1}\end{array}$ & $\begin{array}{l}\text { Shade } \\
\text { tolerance }^{1}\end{array}$ & $\begin{array}{l}\text { Growth } \\
\text { form }^{1}\end{array}$ & $\mathrm{Tc}_{\min }$ & $\mathrm{Tc}_{\max }$ & $T_{W_{\min }}$ & $\mathrm{GDD}_{5}$ \\
\hline Abies alba & EG & temperate & tolerant & tree & $-6.5(-7.5)$ & 2 & 6 & 1600 \\
\hline Betula pendula & SG & temperate & intolerant & tree & -30 & 7 & 5 & 700 \\
\hline Betula pubescens & SG & boreal & intolerant & tree & -30 & 3 & 5 & 350 \\
\hline Carpinus betulus & SG & temperate & intermediate & tree & -8 & 5 & 5 & 1200 \\
\hline Corylus avellana & SG & temperate & intermediate & tree & -11 & 7 & 5 & 800 \\
\hline Fagus sylvatica & SG & temperate & tolerant & tree & -6 & 6 & 5 & 1500 \\
\hline Fraxinus excelsior & SG & temperate & intermediate & tree & -16 & 6 & 5 & 1100 \\
\hline $\begin{array}{l}\text { Juniperus } \\
\text { oxycedrus }\end{array}$ & EG & temperate & intolerant & tree & $1(0)$ & - & - & 2200 \\
\hline Larix decidua & SG & boreal & intermediate & tree & -30 & -2 & 5 & 300 \\
\hline Picea abies & EG & boreal & tolerant & tree & -30 & -1.5 & 5 & 600 \\
\hline Pinus hallipensis & EG & temperate & intolerant & tree & 3 & 9 & 21 & 3000 \\
\hline Pinus sylvestris & EG & boreal & intermediate & tree & -30 & -1 & 5 & 500 \\
\hline Populus tremula & SG & temperate & intolerant & tree & $-30(-31)$ & 6 & - & 500 \\
\hline Quercus coccifera & EG & temperate & intermediate & shrub & 0 & 11 & 21 & 2200 \\
\hline Quercus ilex & EG & temperate & intolerant & tree & 3 & 7 & 5 & 1800 \\
\hline Quercus pubescens & SG & temperate & intermediate & tree & -5 & 6 & - & 1900 \\
\hline Quercus robur & SG & temperate & intermediate & tree & $-9(-10)$ & 6 & 5 & 1100 \\
\hline Tilia cordata & SG & temperate & intermediate & tree & $-11(-12)$ & 5 & 5 & 1100 \\
\hline Ulmus glabra & SG & temperate & intermediate & tree & $-9.5(-10.5)$ & 6 & 5 & 850 \\
\hline $\begin{array}{l}\text { Boreal evergreen } \\
\text { shrub }\end{array}$ & EG & boreal & intolerant* & shrub & - & -1 & - & 200 \\
\hline $\begin{array}{l}\text { Mediterranean } \\
\text { raingreen shrub }\end{array}$ & RG & temperate & intolerant & shrub & $1(0)$ & - & - & 2200 \\
\hline C3 grass & SG/RG & temp-boreal & - & herb & - & - & - & - \\
\hline
\end{tabular}


https://doi.org/10.5194/gmd-2020-440

Preprint. Discussion started: 27 January 2021

(c) Author(s) 2021. CC BY 4.0 License.

Table A1 cont

\begin{tabular}{|c|c|c|c|c|c|c|c|c|c|c|c|}
\hline Species/PFT & $\mathrm{k}_{\text {allom1 }}$ & $\mathrm{k}_{\text {la:sa }}$ & $\begin{array}{c}\operatorname{gmin} \\
\left(\mathrm{mm} \mathrm{s}^{-1}\right)\end{array}$ & $\begin{array}{l}\text { Chilling } \\
\text { requirement }{ }^{1}\end{array}$ & fAWC & $\begin{array}{l}C A_{\max } \\
\left(\mathrm{m}^{2}\right)\end{array}$ & $\overline{z_{1}}$ & $r_{\text {fire }}$ & $\begin{array}{l}\alpha_{\text {leaf }} \\
(y)\end{array}$ & $\begin{array}{r}\alpha_{\text {ind }} \\
(y)\end{array}$ & fnstorage \\
\hline Abies alba & 150 & 4000 & 0.3 & - & 0.35 & 40 & 0.6 & 0.1 & 3 & 350 & 0.05 \\
\hline Betula pendula & 250 & 5000 & 0.5 & intermediate & 0.42 & 40 & 0.6 & 0.1 & 0.5 & 200 & 0.15 \\
\hline Betula pubescens & 250 & 5000 & 0.5 & intermediate & 0.5 & 40 & 0.6 & 0.1 & 0.5 & 200 & 0.15 \\
\hline Carpinus betulus & 250 & 5000 & 0.5 & high & 0.33 & 40 & 0.6 & 0.1 & 0.5 & 350 & 0.15 \\
\hline Corylus avellana & 250 & 4000 & 0.5 & intermediate & 0.3 & 40 & 0.6 & 0.1 & 0.5 & 100 & 0.15 \\
\hline Fagus sylvatica & 250 & 5000 & 0.5 & high & 0.3 & 40 & 0.6 & 0.1 & 0.5 & 500 & 0.15 \\
\hline Fraxinus excelsior & 250 & 5000 & 0.5 & low & 0.4 & 40 & 0.6 & 0.1 & 0.5 & 350 & 0.15 \\
\hline $\begin{array}{l}\text { Juniperus } \\
\text { oxycedrus }\end{array}$ & 150 & 1500 & 0.5 & - & 0.01 & 10 & 0.5 & 0.4 & 1.5 & 200 & 0.05 \\
\hline Larix decidua & 150 & 5000 & 0.3 & low & 0.3 & 40 & 0.6 & 0.2 & 1 & 500 & 0.05 \\
\hline Picea abies & 150 & 4000 & 0.3 & - & 0.43 & 40 & 0.8 & 0.1 & 3 & 500 & 0.05 \\
\hline Pinus hallipensis & 150 & 3000 & 0.3 & - & 0.05 & 40 & 0.6 & 0.2 & 2 & 350 & 0.05 \\
\hline Pinus sylvestris & 150 & 3000 & 0.3 & - & 0.25 & 40 & 0.6 & 0.2 & 2 & 350 & 0.05 \\
\hline Populus tremula & 250 & 5000 & 0.5 & intermediate & 0.4 & 40 & 0.7 & 0.2 & 0.5 & 160 & 0.15 \\
\hline Quercus coccifera & 100 & 2500 & 0.5 & - & 0.1 & 10 & 0.5 & 0.3 & 1.5 & 350 & 0.3 \\
\hline Quercus ilex & 250 & 3000 & 0.5 & - & 0.1 & 40 & 0.5 & 0.3 & 2 & 350 & 0.05 \\
\hline Quercus pubescens & 250 & 5000 & 0.5 & low & 0.2 & 40 & 0.6 & 0.2 & 0.5 & 500 & 0.15 \\
\hline Quercus robur & 250 & 5000 & 0.5 & low & 0.25 & 40 & 0.6 & 0.2 & 0.5 & 500 & 0.15 \\
\hline Tilia cordata & 250 & 5000 & 0.5 & high & 0.33 & 40 & 0.8 & 0.1 & 0.5 & 350 & 0.15 \\
\hline Ulmus glabra & 250 & 5000 & 0.5 & low & 0.4 & 40 & 0.6 & 0.1 & 0.5 & 350 & 0.15 \\
\hline $\begin{array}{l}\text { Boreal evergreen } \\
\text { shrub }\end{array}$ & 20 & 500 & 0.3 & - & 0.25 & 3 & 0.8 & 0.1 & 2 & 50 & 0.3 \\
\hline $\begin{array}{l}\text { Mediterranean } \\
\text { raingreen shrub }\end{array}$ & 100 & 1500 & 0.5 & - & 0.01 & 10 & 0.9 & 0.3 & 0.5 & 100 & 0.3 \\
\hline C3 grass & - & - & 0.03 & - & 0.01 & - & 0.9 & 0.5 & 0.5 & - & 0.3 \\
\hline
\end{tabular}

${ }^{1}$ See group parameter table $2 ; \mathrm{k}_{\text {allom1 }}=$ constant in allometry equations (Smith et al., 2001); $\mathrm{k}_{\text {la:sa }}=$ leaf area to sapwood crosssectional area ratio; gmin $=$ minimum canopy conductance; $f A W C=$ minimum growing-season (daily temperature $>5^{\circ} \mathrm{C}$ )

fraction of available soil water holding capacity in the first soil layer; $C A_{\max }=$ maximum woody crown area; $z_{l}=$ fraction of roots in first soil layer; $r_{\text {fire }}=$ fraction of individuals surviving fire; $a_{\text {leaf }}=$ leaf longevity; $a_{\text {ind }}=$ maximum, non-stressed longevity; fnstorage: fraction of sapwood (root for herbaceous pfts) that can be used as a nitrogen longterm storage scalar 
Table A2. Common PFT parameters for shade tolerance, geographic range, growth form and chilling requirement categories in Table A1. Values in bold cursive text are updated compared to Hickler et al 2012.

\begin{tabular}{|c|c|c|c|}
\hline Shade tolerance & tolerant & intermediate & intolerant \\
\hline Sapwood to heartwood conversion rate $\left(\text { year }^{-1}\right)^{*}$ & 0.05 & 0.075 & 0.1 \\
\hline Growth efficiency parameter $\left(\mathrm{kg} \mathrm{C} \mathrm{m}^{-2}\right.$ year $\left.^{-1}\right)$ & 0.04 & 0.06 & 0.08 \\
\hline Max. establishment rate (saplings year-1 $\mathrm{m}^{-2}$ ) & 0.05 & 0.15 & 0.2 \\
\hline Min. PAR at forest floor for establishment $\left(\mathrm{MJ} \mathrm{m}^{-2}\right.$ day $\left.^{-1}\right)$ & 0.35 & 2.0 & 2.5 \\
\hline Recruitment shape parameter & 3 & 7 & 10 \\
\hline \multicolumn{4}{|l|}{ *Boreal evergreen shrub: 0.05} \\
\hline Geographic range & boreal & temperate & $\begin{array}{l}\text { temperate- } \\
\text { boreal grass }\end{array}$ \\
\hline Base respiration rate at $10^{\circ} \mathrm{C}\left(\mathrm{gC} \mathrm{gN}^{-1}\right.$ day- $\left.^{1}\right)$ & 1 & 1 & 1 \\
\hline Optimum temperature range for photosynthesis $\left({ }^{\circ} \mathrm{C}\right)$ & $10-25$ & $15-25$ & $10-30$ \\
\hline pstemp_min & -4 & -2 & -5 \\
\hline pstemp_max & 38 & 38 & 45 \\
\hline Growth form & tree & shrub & herbaceous \\
\hline $\mathrm{k}_{\text {allom2} \text { (allometric parameter) }}$ & 40 & 5 & - \\
\hline wooddens & 200 & 250 & - \\
\hline $1 r_{\max }$ Non water-stressed leaf to fine root mass ratio & 1 & 1 & 0.5 \\
\hline Fine root turnover rate $\left(\right.$ year $\left.^{-1}\right)$ & 0.7 & 0.7 & 0.7 \\
\hline Chilling requirement & low & intermediate & high \\
\hline k_chilla & 0 & 0 & 0 \\
\hline k_chillb & 100 & 350 & 600 \\
\hline k_chillk & 0.05 & 0.05 & 0.05 \\
\hline
\end{tabular}

Table A3. Parameters for automated thinning and clearcut.

\begin{tabular}{ccccc}
\hline & $\begin{array}{c}\boldsymbol{\alpha}_{\text {st }} \\
\left(\text { trees ha }^{-1}\right)\end{array}$ & $\begin{array}{c}\boldsymbol{\beta}_{\text {st }} \\
\log \left(\text { trees ha }^{-1}\right)(\operatorname{log~m})^{-1}\end{array}$ & $\boldsymbol{r d i}_{\text {target }}$ & $\begin{array}{c}\text { dens }_{\text {target }} \\
\left(\text { trees ha }^{-1}\right)\end{array}$ \\
\hline Needleleaf (NL) & 65 & 1.6 & 0.7 & 250 \\
Broadleaf (BL) & 40 & 1.6 & 0.85 & 100 \\
\hline
\end{tabular}


https://doi.org/10.5194/gmd-2020-440

Preprint. Discussion started: 27 January 2021

(C) Author(s) 2021. CC BY 4.0 License.

Appendix B: Supplementary model initialisation and management options figures.

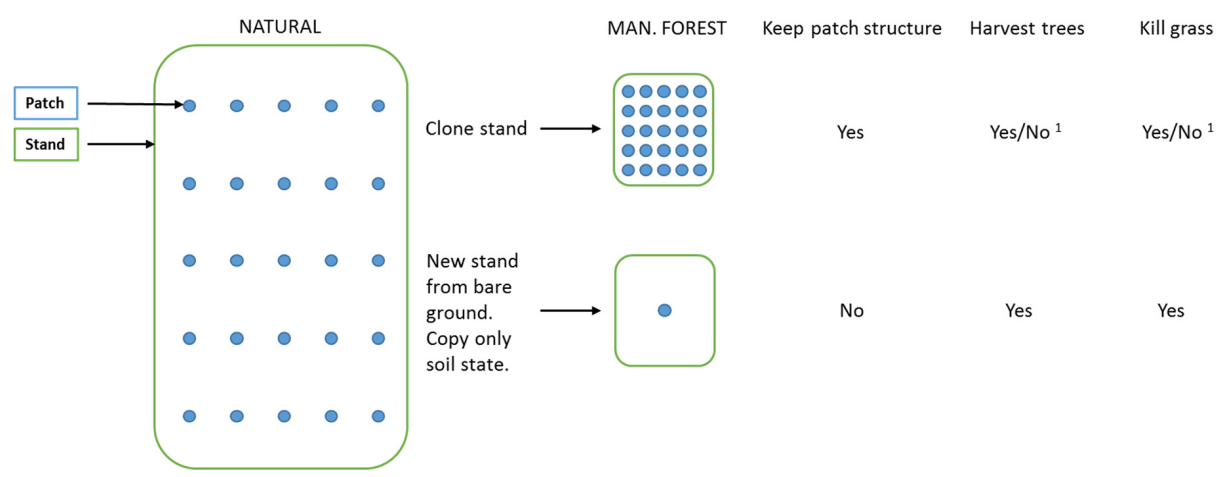

Figure B1. Options when creating managed forest stands from PNV. ${ }^{1}$ For the cloning alternative, tree harvest and grass killing is optional.

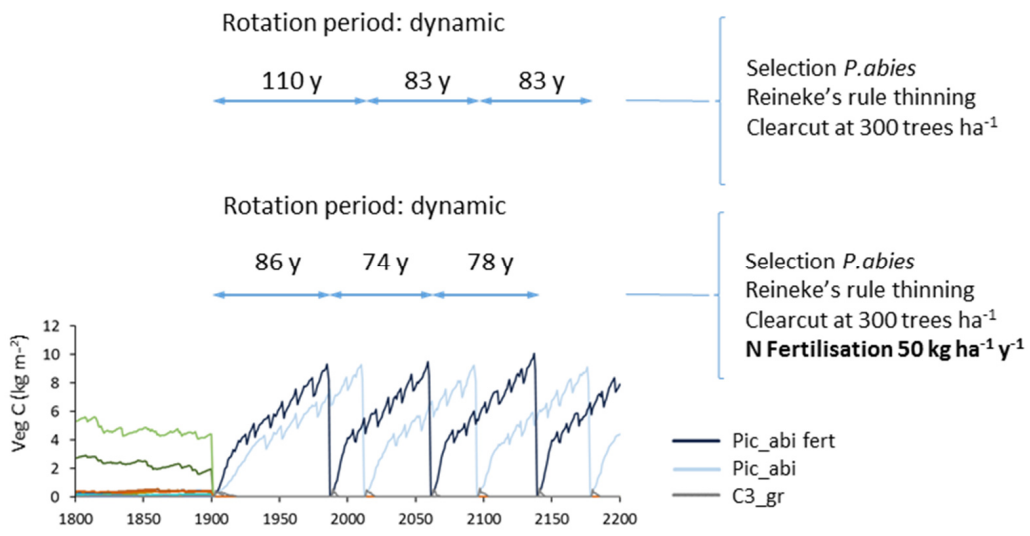

Figure B2. Effect of nitrogen fertilisation $\left(50 \mathrm{~kg} \mathrm{ha}^{-1} \mathrm{y}^{-1}\right)$ on modelled productivity and rotation length in spruce monoculture with automated thinning and clearcut. Abbreviations: Pic_abi fert: Picea abies with $\mathbf{N}$ fertilisation, Pic_abi: Picea abies without $\mathbf{N}$ fertilisation, C3_gr: C3 grass. Forestry stands were created from clearcut of PNV in 1901. Location, climate input and species in PNV as in Fig. 2. 
Appendix C: Supplementary European simulation setup tables and figures.

Table C1. Mapping of EFI tree groups to LPJ-GUESS species selections ${ }^{1}$

\begin{tabular}{|c|c|}
\hline EFI species group & LPJ-GUESS selection \\
\hline \multicolumn{2}{|l|}{ Broadleaf deciduous (BD) } \\
\hline Alnus, Betula & B. pendula, B. pubescens \\
\hline BroadleafMisc, Castanea, Robinia & B. pendula, B. pubescens, C. avellana, Q. pubescens, T. cordata, U. glabra \\
\hline Carpinus & C. betulus \\
\hline Fagus & F. sylvatica \\
\hline Fraxinus & F. excelsior \\
\hline Populus & P. tremula \\
\hline QuercusRobPet & Q. robur \\
\hline None $^{2}$ & B. pubescens, $F$. sylvatica, Q. robur, C. avellana \\
\hline Undet. $^{3}$ & $\begin{array}{l}\text { B. pendula, B. pubescens, C. betulus, } C \text {. avellana, } F \text {. sylvatica, F.excelsior, } \\
P . \text { tremula, Q. pubescens, } Q \text {. robur, T. cordata, U.glabra }\end{array}$ \\
\hline \multicolumn{2}{|l|}{ Broadleaf evergreen (BE) } \\
\hline QuercusMisc, Eucalypus & Q. ilex \\
\hline \multicolumn{2}{|l|}{ Needleleaf deciduous (ND) } \\
\hline Larix & L. decidua \\
\hline \multicolumn{2}{|l|}{ Needleleaf evergreen (NE) } \\
\hline Abies & A. alba \\
\hline Conifers, Pseudotsuga & P. abies, $P$. sylvestris, $P$. halepensis \\
\hline Picea & P. abies \\
\hline PinusSylv & P. sylvestris \\
\hline PinusMisc, PinusPin & P. sylvestris, $P$. halepensis \\
\hline None $^{2}$ & P. abies, $P$. sylvestris \\
\hline Undet. $^{3}$ & A. alba, $P$. abies, $P$. sylvestris \\
\hline \multicolumn{2}{|c|}{ 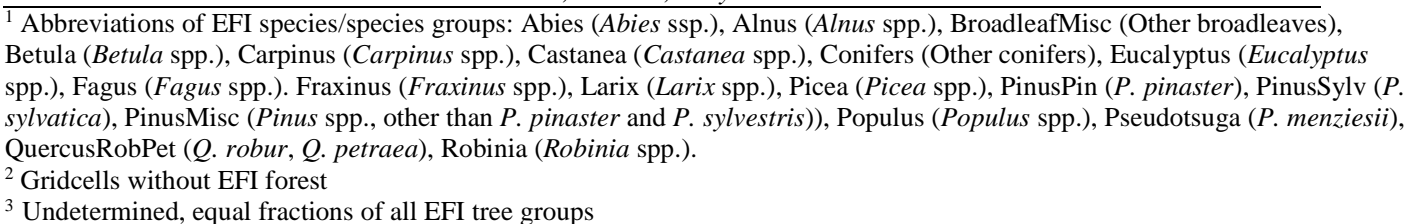 } \\
\hline
\end{tabular}


https://doi.org/10.5194/gmd-2020-440

Preprint. Discussion started: 27 January 2021

(c) Author(s) 2021. CC BY 4.0 License.

(a) P.abies

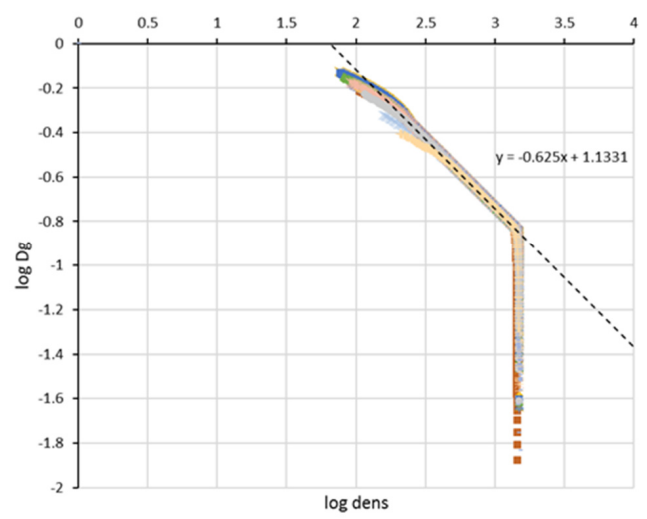

(b) F.sylvatica
- N. Karelia $\left(65.25^{\circ} \mathrm{N}, 30.25^{\circ} \mathrm{E}\right)$

$\Delta \quad$ S. Sweden $\left(55.75^{\circ} \mathrm{N}, 13.25^{\circ} \mathrm{E}\right)$ Scotland $\left(55.25^{\circ} \mathrm{N}, 2.75^{\circ} \mathrm{W}\right)$

* Schlesvig-Holstein $\left(53.75^{\circ} \mathrm{N}, 10.25^{\circ} \mathrm{E}\right)$

- England $\left(52.75^{\circ} \mathrm{N}, 0.25^{\circ} \mathrm{W}\right)$

$+\quad$ Bialowieza $\left(52.75^{\circ} \mathrm{N}, 23.75^{\circ} \mathrm{E}\right)$

Czech rep. $\left(50.25^{\circ} \mathrm{N}, 14.25^{\circ} \mathrm{E}\right)$

- Bavaria $\left(50.25^{\circ} \mathrm{N}, 9.75^{\circ} \mathrm{E}\right)$

- N. France $\left(48.25^{\circ} \mathrm{N}, 2.25^{\circ} \mathrm{E}\right)$

- Slovenia $\left(46.25^{\circ} \mathrm{N}, 14.75^{\circ} \mathrm{E}\right)$

$\triangle \quad$ Lombardy $\left(45.75^{\circ} \mathrm{N}, 9.25^{\circ} \mathrm{E}\right)$ E. Bulgaria $\left(43.75^{\circ} \mathrm{N}, 27.75^{\circ} \mathrm{E}\right)$ Galicia $\left(43.25^{\circ} \mathrm{N}, 7.75^{\circ} \mathrm{W}\right)$ Albania $\left(41.75^{\circ} \mathrm{N}, 20.25^{\circ} \mathrm{E}\right)$ Apulia $\left(40.75^{\circ} \mathrm{N}, 17.25^{\circ} \mathrm{E}\right)$ S. Spain $\left(37.75^{\circ} \mathrm{N}, 0.75^{\circ} \mathrm{W}\right)$

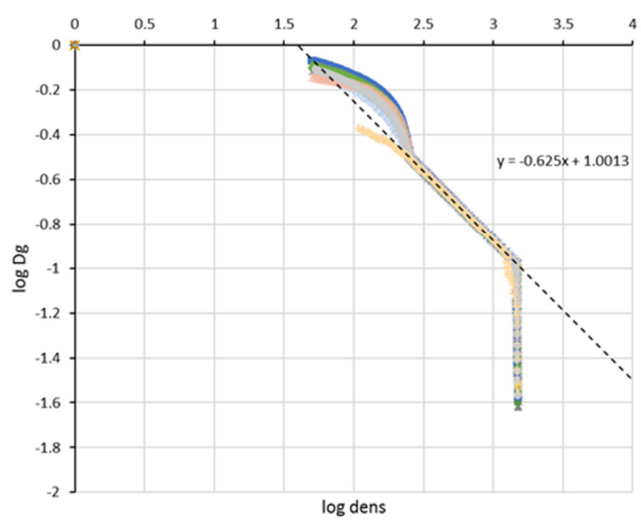

Figure C1. Self-thinning log-log plots of quadratic mean diameter (Dg) and tree density (dens) for simulations of (a) Picea abies and (b) Fagus sylvatica monoculture at 16 European sites used for automated thinning in the model. 
https://doi.org/10.5194/gmd-2020-440

Preprint. Discussion started: 27 January 2021

(c) Author(s) 2021. CC BY 4.0 License.

EFI dominant species

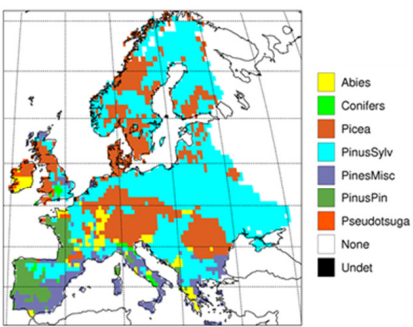

$\mathrm{BD}$

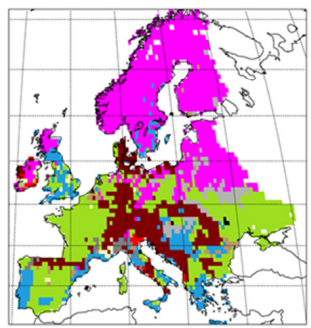

LPJ-GUESS species selection
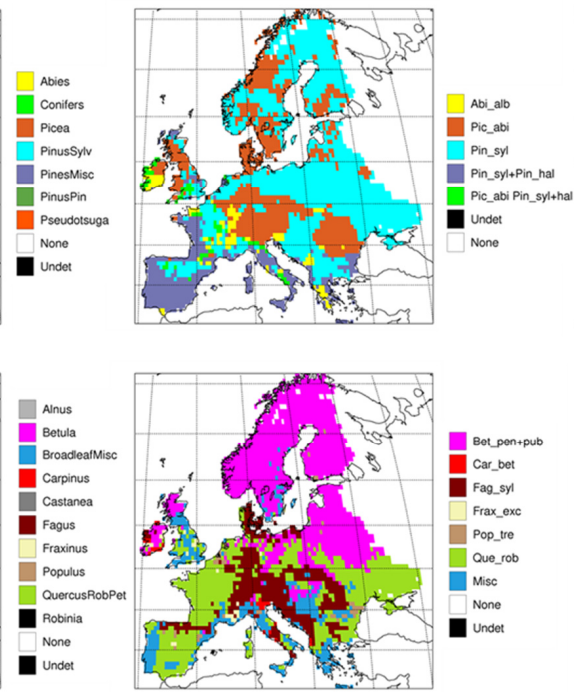

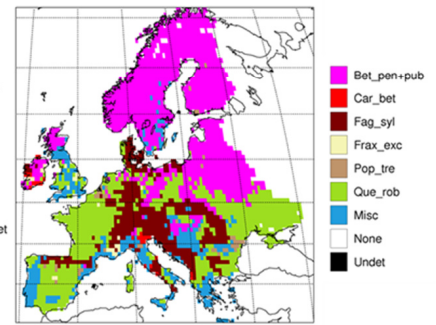

LPJ-GUESS dominant species
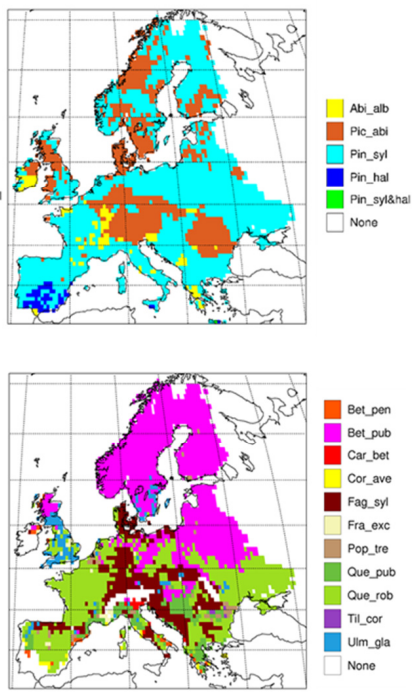

Figure C2. Mapping of dominant EFI tree species groups in the needleleaf evergreen (NE) and broadleaf deciduous (BD) GFAD forest classes to LPJ-GUESS species selections and the resulting dominant species (LAI) in 1986-2015 in an LPJ-GUESS simulation with automated thinning. Abbreviations of EFI species/species groups: Abies (Abies ssp.), Alnus (Alnus spp.), BroadleafMisc (Other broadleaves), Betula (Betula spp.), Carpinus (Carpinus spp.), Castanea (Castanea spp.), Conifers (Other conifers), Eucalyptus (Eucalyptus spp.), Fagus (Fagus spp.). Fraxinus (Fraxinus spp.), Larix (Larix spp.), Picea (Picea spp.), PinusPin (P. pinaster), PinusSylv (P. sylvatica), PinusMisc (Pinus spp., other than P. pinaster and P.sylvestris), Populus (Populus spp.), Pseudotsuga (P. menziesii), QuercusRobPet $(Q$. robur, $Q$. petraea), Robinia (Robinia spp.). Abbreviations of LPJ-GUESS species/species groups: Abi_alb (A.alba),

Pic_abi (P.abies), Pin_syl (P.sylvestris), Pin_hal (P.halipensis), Pin_syl+hal (P.sylvestris+P.halipensis), Bet_pen (B.pendula), Bet_pub (B.pubescens), Bet_pen+pub (B.pendula+B.pubescens), Car_bet (C.betulus), Cor_ave (C.avellana), Fag_syl (F.sylvestris), Frax_exc (F.excelsior), Pop_tre (P.tremula), Que_rob (Q.robur), Que_pub (Q.pubescens), Til_cor (T.cordata), Ulm_gla (U.glabra). The EFI groups BroadleafMisc, Castanea and Robinia are mapped to the LPJ-GUESS selection "Misc": B.pendula, B.pubescens, C.avellana, Q.pubescens, T.cordata and U.glabra. For the mapping of the EFI groups None and Undet, see Table C1.

EFI dominant species

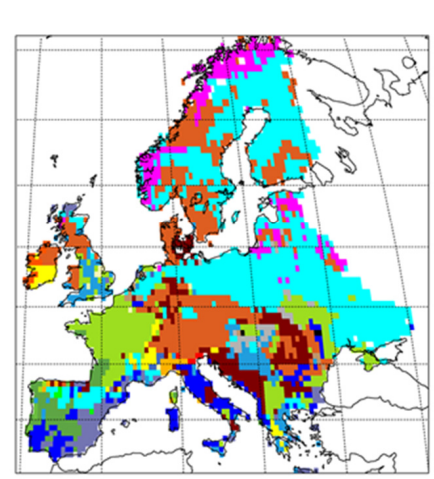

\section{LPJ-GUESS dominant species}

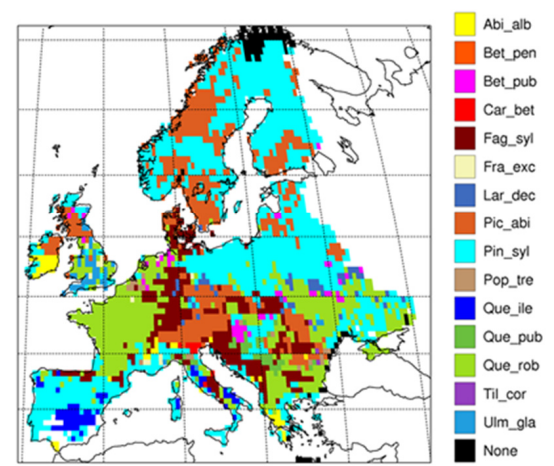

Figure C3. Comparison of dominant EFI tree species groups (area) and modelled LPJ-GUESS managed forest dominant tree species (LAI) in 1986-2015 in an LPJ-GUESS simulation with automated thinning. Abbreviations of LPJ-GUESS species as in Fig. C2. 
(a)

PNV dominant species

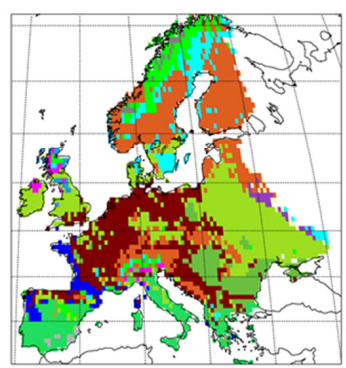

(b)

Managed forest dominant species

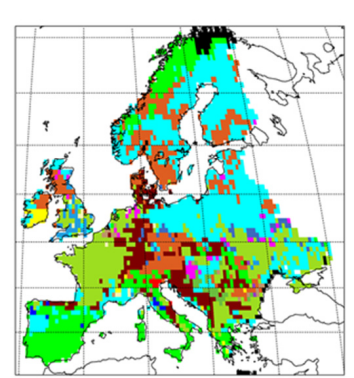

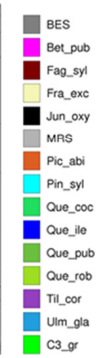

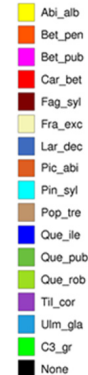

(c)

Total forest dominant species

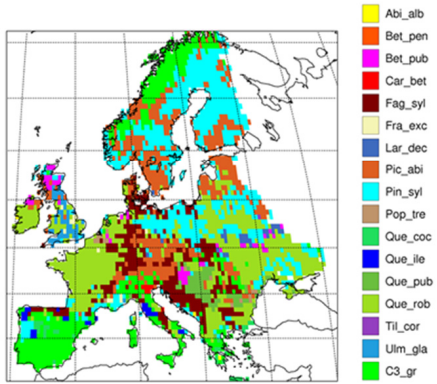

Figure C4. Modelled LPJ-GUESS dominant species (LAI) (including grass) in A. Primary forest (modelled as PNV), B. secondary forest (managed with automated thinning) and C. total forest landscape in 1986-2015. Abbreviations of LPJ-GUESS tree species as in Fig. C2, BES (Boreal evergreen shrub), MRS (Mediterranean raingreen shrub), C3_gr (C3 grass).

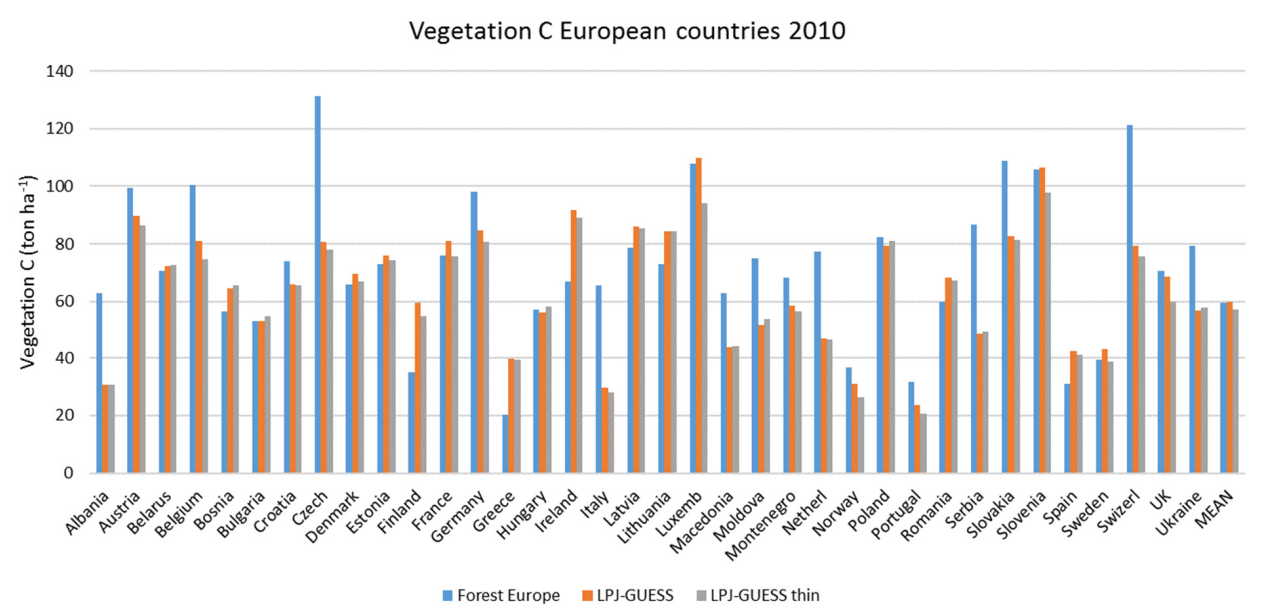

Figure D1. Modelled and observed (Forest Europe 2015) vegetation carbon for individual countries in 2001-2010. LPJ-GUESS: simulation without thinning, LPJ-GUESS thin: simulation with automated thinning. 
https://doi.org/10.5194/gmd-2020-440

Preprint. Discussion started: 27 January 2021

(c) Author(s) 2021. CC BY 4.0 License.

Total C pool European countries 2010

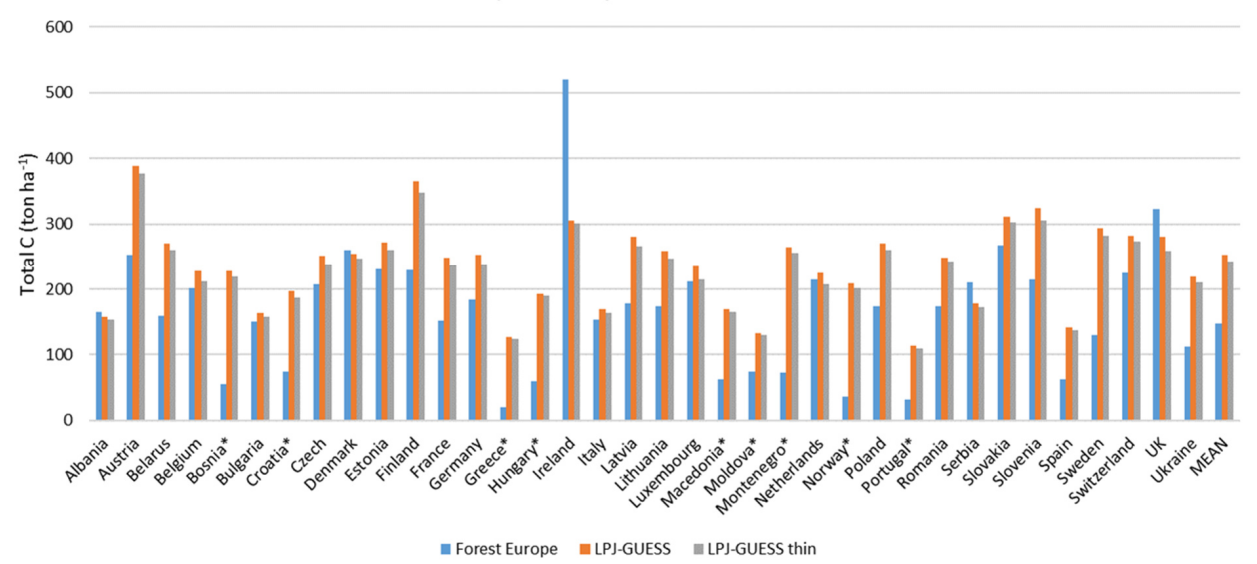

Figure D2. Modelled and observed (Forest Europe 2015) total carbon pool for individual countries in 2001-2010. LPJ-GUESS: simulation without thinning, LPJ-GUESS thin: simulation with automated thinning. *Soil and litter carbon data missing for Bosnia, Croatia, Greece, Hungary, Macedonia, Moldova, Montenegro, Norway and Portugal.

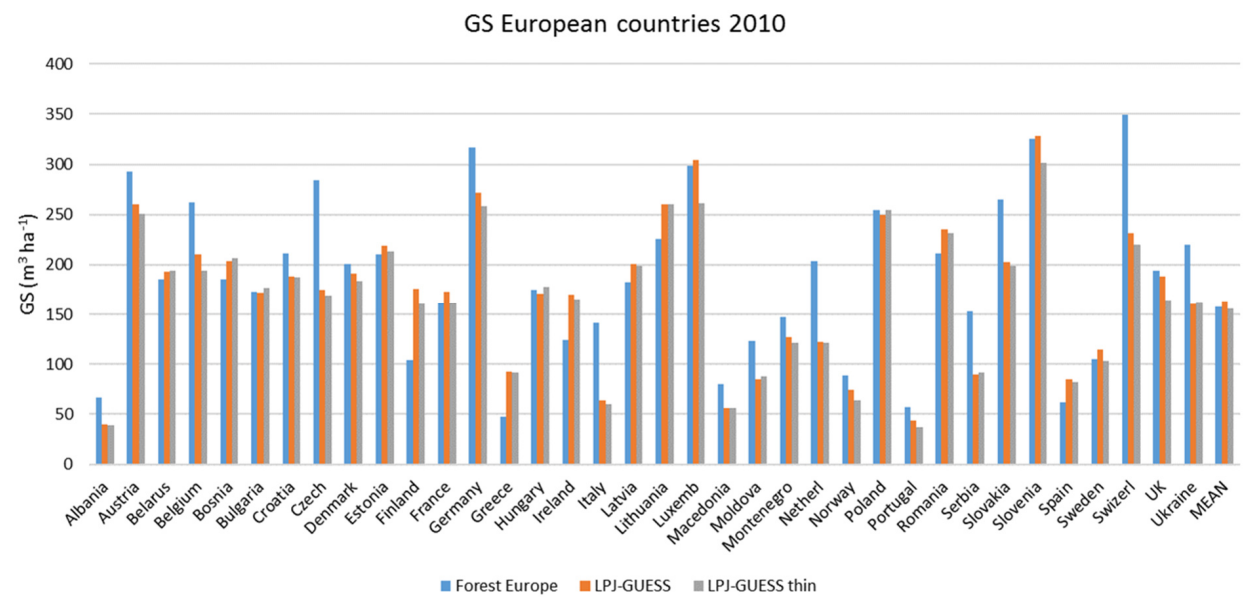

Figure D3. Modelled and observed (Forest Europe 2015) growing stock (GS) for individual countries in 2001-2010. LPJ-GUESS: simulation without thinning, LPJ-GUESS thin: simulation with automated thinning. 
https://doi.org/10.5194/gmd-2020-440

Preprint. Discussion started: 27 January 2021

(c) Author(s) 2021. CC BY 4.0 License.

NAI European countries 2000-2010

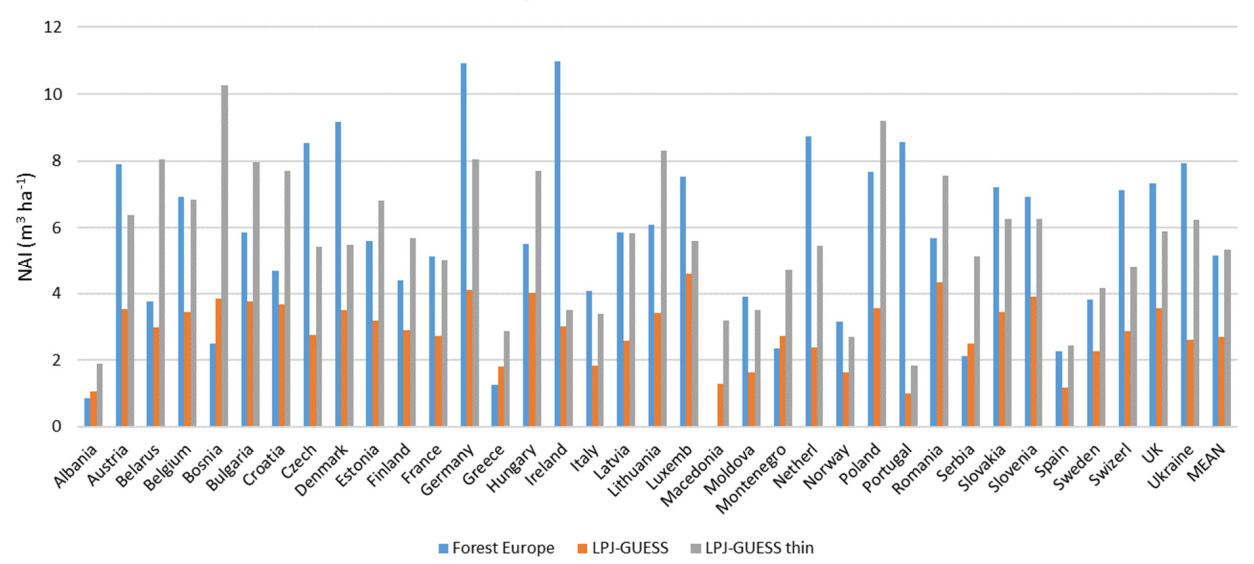

Figure D4. Modelled and observed (Forest Europe 2015) net annual increase (NAI) for individual countries in 2001-2010. LPJ-GUESS: simulation without thinning, LPJ-GUESS thin: simulation with automated thinning.

Fellings European countries 2001-2010

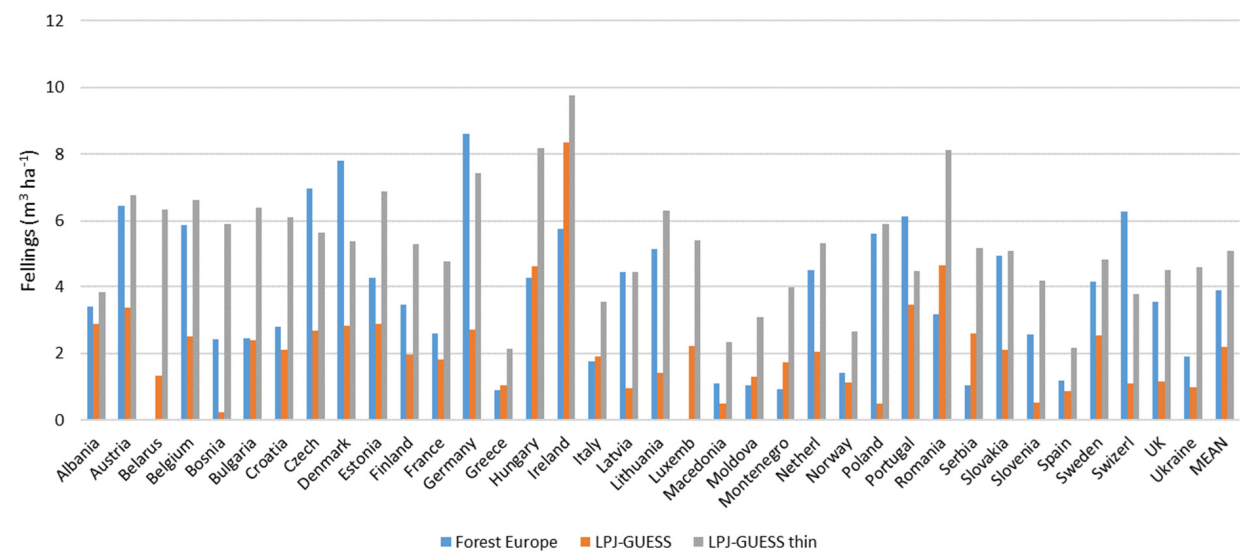

Figure D5. Modelled and observed (Forest Europe 2015) yearly fellings for individual countries in 2001-2010. LPJ-GUESS: simulation without thinning (clearcuts at creation of secondary forest), LPJ-GUESS thin: simulation with automated thinning. Observations are missing for Belarus and Luxembourg. 
(a)

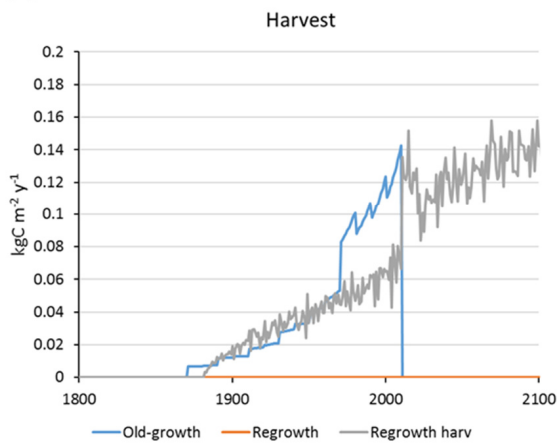

(b)

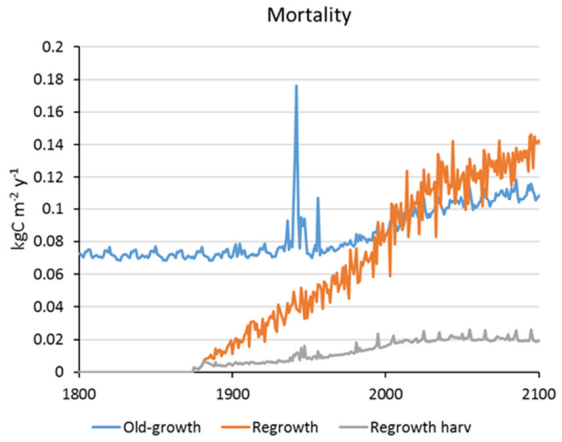

Figure D6. Simulation of European old-growth and regrowth forests with (Regrowth harv) and without (Regrowth) wood harvest in regrowth forests using historic CRU-NCEP climate, recycling the last 30 data years after 2015. (a) Harvested carbon. Old-growth harvests are clearcuts at the creation of secondary (regrowth) stands in the period 1870-2010. The spike in regrowth forest harvest in 2011-2020 is due to delayed clearcuts of stands passing the tree density limit for clearcut before 2010. (b) Vegetation carbon lost in natural mortality.

(a)

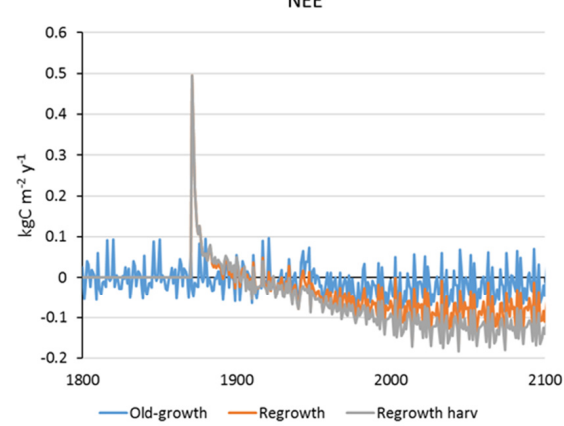

(c)

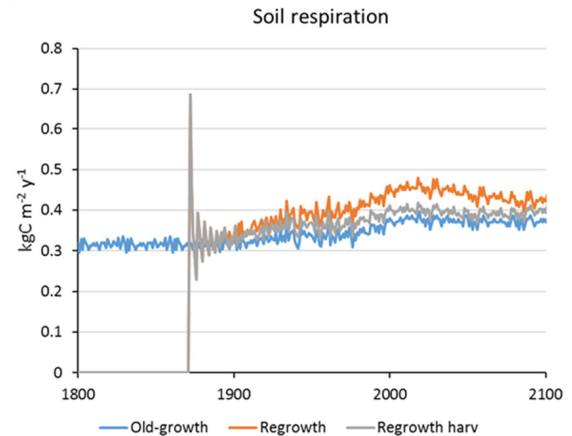

(b)

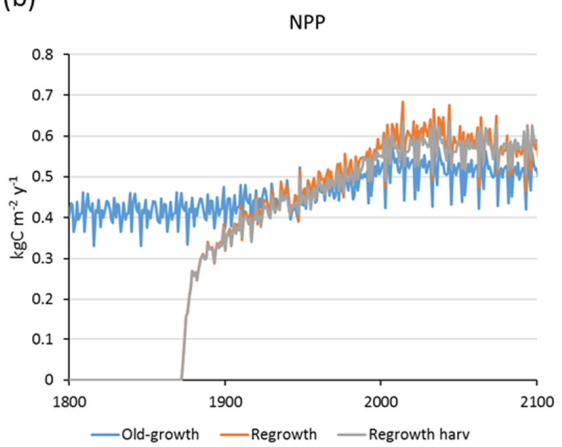

(d)

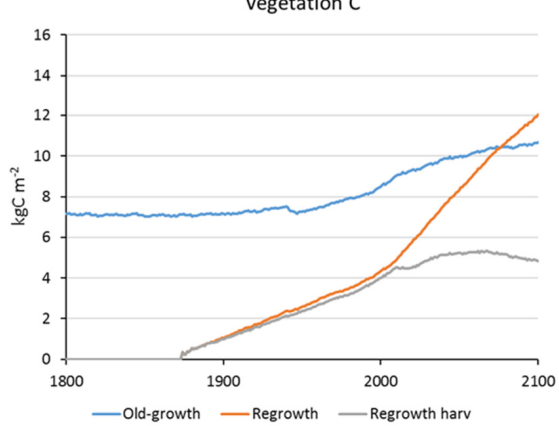

Figure D7. Simulation of European old-growth and regrowth forests with and without wood harvest in regrowth forests using historic CRU-NCEP climate, recycling the last 30 data years after 2015. (a) Net ecosystem exchange (NEE). (b) Net primary productivity (NPP). (c) Soil heterotrophic respiration. (d). Vegetation carbon. Some NEE componenets are not show, e.g. carbon allocated to reproduction and fire in old-growth forest. 
https://doi.org/10.5194/gmd-2020-440

Preprint. Discussion started: 27 January 2021

(c) Author(s) 2021. CC BY 4.0 License.

(a)

20602160

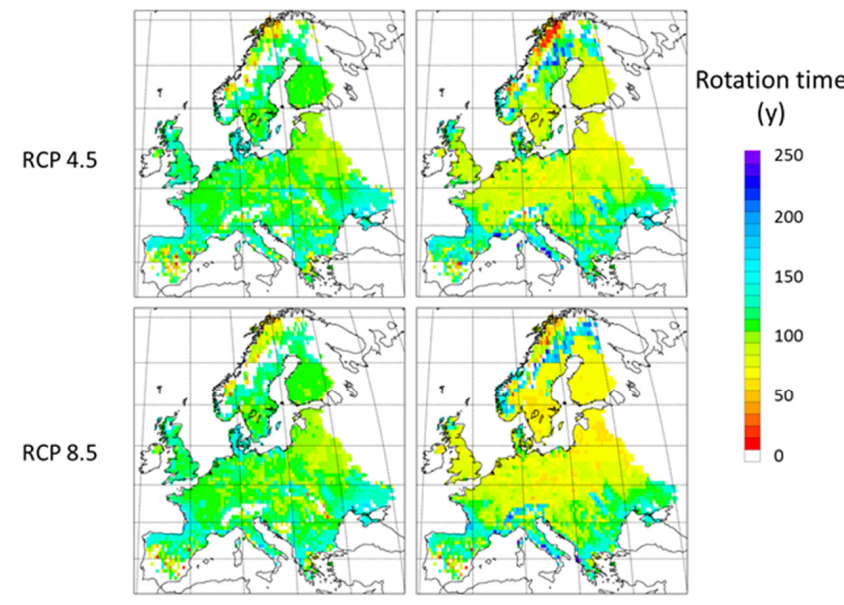

(b)

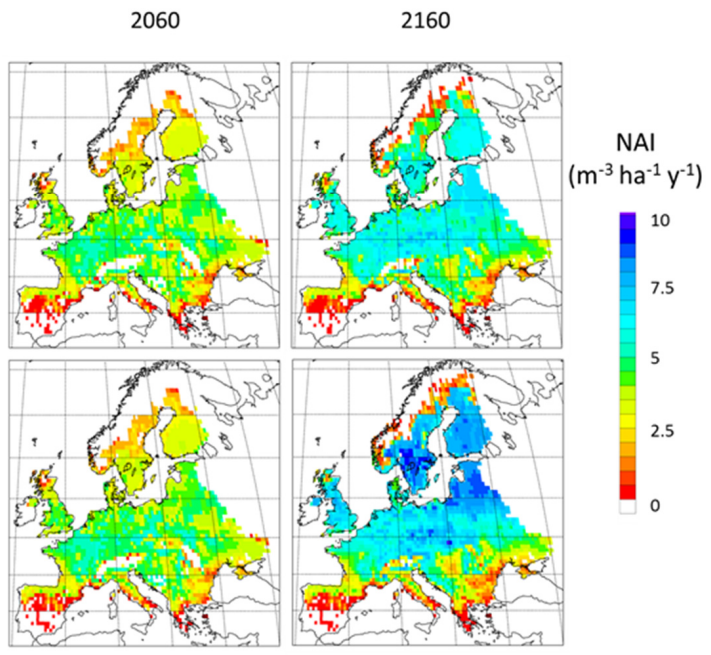

Figure D8. Simulations of broadleaf forests using automated thinning and clearcut under RCP 4.5 and RCP $8.5 \mathrm{CO}_{2} / \mathrm{climate}$, recycling the the last 30 climate data years after 2100. (a) Mean rotation time for the latest clearcut events in each stand in 2060 and 2160 . (b) Mean net annual increase (NAI) during the latest rotations in each stand in 2060 and 2160 . For the expansion from total vegetation carbon to wood volume, a wood volume/vegetation carbon ratio of $2.7 \mathrm{~m}^{3} \mathrm{tC}^{-1}$ was used. 


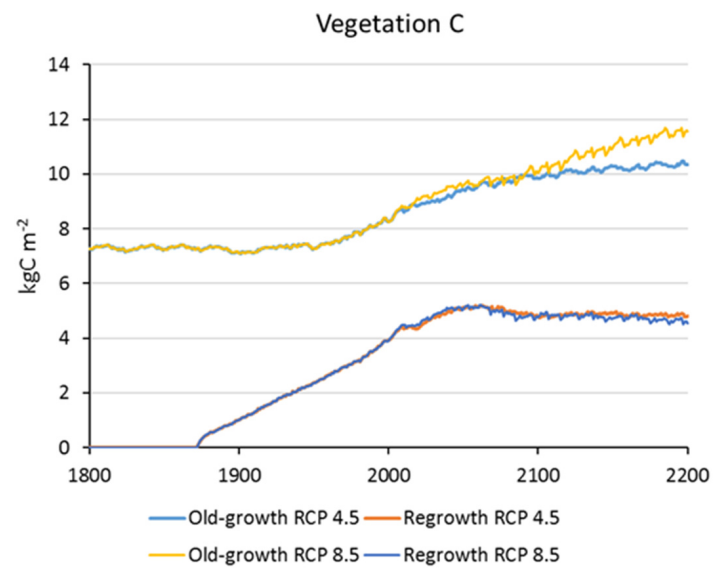

Figure D9. Simulations of European forests using automated thinning and clearcut in regrowth forests under RCP4.5 and RCP8.5 $\mathrm{CO}_{2}$ /climate, recycling the the last 30 data years after 2100.. Vegetation carbon in old-growth and regrowth forests. Old-growth forests are simuated as PNV.

Code availability. LPJ-GUESS development is managed and the code maintained in a permanent repository at Lund University, Sweden. Source code is normally made available on request to research users. Conditions apply in the case of model versions still under active development. The model version presented in this paper is identified by the permanent revision number r 9333 in the code repository. There is no DOI associated with the code.

Author contributions. ML and FL developed the forestry model code. ML and AR designed the simulations. ML performed the simulations and designed and performed the analyses. All authors contributed to the manuscript.

Competing interests. The authors declare that they have no conflict of interest.

Acknowledgements. This study was funded by the Swedish Research Council Formas through the ERA-Net SUMFOREST project Forests and extreme weather events: Solutions for risk resilient management in a changing climate (FOREXCLIM) (dnr. 201602110) and the project Land Use, Carbon Sinks and Negative Emissions for Climate Targets (dnr. 2016-01201) and also by the German Federal Office for Agriculture and Food (BLE) through the FOREXCLIM project. The study also contributes to the Strategic Research Areas BECC and MERGE. AR acknowledges funding from the the Bavarian Ministry of Science and the Arts (grant no. BayKliF). The computations were enabled by resources provided by the Swedish National Infrastructure for Computing (SNIC) at LUNARC, Lund University, partially funded by the Swedish Research Council through grant agreement no. 2019/3592

\section{References}

Ahlström, A., Schurgers, G., Arneth, A., and Smith, B.: Robustness and uncertainty in terrestrial ecosystem carbon response to 
Anderegg, W. R. L., Kane, J. M., and Anderegg, L. D. L.: Consequences of widespread tree mortality triggered by drought and temperature stress, Nat. Clim. Change, 3, 30-36, doi:10.1038/nclimate1635, 2013.

Bellassen, V., Le Maire, G., Dhôte, J.F., and Viovy, N.: Modelling forest management within a global vegetation model - Part 1: Model Structure and general behaviour, Ecol. Model., 221, 2458-2474. doi:10.1016/j.ecolmodel.2010.07.008, 2010.

Bonan, G.B.: Forests and climate change: forcings, feedbacks and the climate benefits of forests, Science, 320, 1444-1449, doi:10.1126/science.1155121, 2008.

Brus, D.J., Hengeveld, G.M., Walvoort, D.J.J., Goedhart, P.W., Heidema, A.H., Nabuurs, G.J., Gunia, K.: Statistical mapping of tree species over Europe, Eur. J. Forest Res., 131, 145-157, doi:10.1007/s10342-011-0513-5, 2011.

Cardellini, G., Valada, T., Cornillier, C., Vial, E., Dragoi, M., Goudiaby, V., Mues, V., Lasserre, B., Gruchala, A., Rorstad, P.K., Neumann, M., Svoboda, M., Sirgments, R., Näsärö, O.-P., Mohren, F., Achten, W.M.J., Vranken, L. and Muys, B.: EFO-LCI: A New Life Cycle Inventory Database of Forestry Operations in Europe, Environ. Manage., 61, 1031-1047. doi:10.1007/s00267018-1024-7, 2018.

Ciais, P., Schelhaas, M., Zaehle, S., Piao, S.L., Cescatti, A., Liski, J., Luyssaert, S., Le-Maire, G., Schulze, E.-D., Bouriaud, O., Freibauer, A., Valentini, R. and Nabuurs, G.J.: Carbon accumulation in European forests, Nature Geosci. 1, 425-429, doi:10.1038/ngeo233, 2008.

Dufresne, J. L. et al.: Climate change projections using the IPSL-CM5 Earth System Model: from CMIP3 to CMIP5, Clim. Dynam., 40, 2123-2165, doi:10.1007/s00382-012-1636-1, 2013.

Easterling, D. R., Meehl, G. A., Parmesan, C., Changnon, S. A., Karl, T. R., and Mearns, L. O.: Climate extremes: Observations, modeling, and impacts, Science, 289, 2068-2074, doi:10.1126/science.289.5487.2068, 2000.

FOREST EUROPE: State of Europe's Forests 2015. Ministerial Conference on the Protection of Forests in Europe, Forest Europe, Liaison Unit Madrid, Madrid. Spain. http://foresteurope.org/state-europes-forests-2015-report/, 2015.

Guo, L. B. and Gifford, R. M.: Soil carbon stocks and land use change: a meta analysis, Glob. Change Biol., 8, 345-360. doi:10.1046/j.1354-1013.2002.00486.x, 2002.

Heinimann A., Mertz O., Frolking S., Egelund Christensen A., Hurni K., Sedano F., et al.: A global view of shifting cultivation: Recent, current, and future extent, PLoS ONE, 12, e0184479, doi:10.1371/journal.pone.0184479, 2017.

Hickler, T., Smith, B., Sykes, M. T., Davis, M. B., Walker, K., and Sugita, S.: Using a Generalized Vegetation Model to Simulate Vegetation Dynamics in Northeastern USA, Ecology, 85, 519-530, doi:10.1890/02-0344, 2004.

Hickler, T., Vohland, K., Feehan, J., Miller, P.A., Smith, B., Costa, L., Giesecke, T., Fronzek, S., Carter, T.R., Cramer, W., Kühn, I., and Sykes, M.T.: Projecting the future distribution of European potential natural vegetation zones with a generalized, tree species-based dynamic vegetation model, Global Ecol. Biogeogr., 21, 50-63, doi:10.1111/j.1466-8238.2010.00613.x, 2012.

Houghton, R. A., House, J. I., Pongratz, J., van der Werf, G. R., DeFries, R. S., Hansen, M. C., Le Quéré, C., and Ramankutty, N.: Carbon emissions from land use and land-cover change, Biogeosciences, 9, 5125-5142. doi:10.5194/bg-9-5125-2012, 2012.

Jiang, M., Medlyn, B.E., Drake, J.E. et al.: The fate of carbon in a mature forest under carbon dioxide enrichment, Nature, 580, 227-231, doi:10.1038/s41586-020-2128-9, 2020.

Jönsson, A.-M., Schroeder, L.M., Lagergren, F., Anderbrant, O. and Smith, B.: Guess the impact of Ips typographus - An ecosystem modelling approach for simulating bark beetle outbreaks, Agr. Forest Meteorol., 166-167, 188-200, doi: 10.1016/j.agrformet.2012.07.012, 2012.

Krause, A., Knoke, T. and Rammig, A.: A regional assessment of land-based carbon mitigation potentials: bioenergy, BECCS, reforestation, and forest management, Glob. Change Biol. Bioenergy, 12, 346-360, 2020. 
Lagergren, F., Jönsson, A.-M., Blennow, K. and Smith, B.: Implementing storm damage in a dynamic vegetation model for regional applications in Sweden, Ecol. Model., 247, 71-82, doi:10.1111/gcbb.12675, 2012.

Le Quéré C, et al.: Global carbon budget 2017, Earth Syst. Sci. Data, 10, 405-448, doi:10.5194/essd-10-405-2018, 2018.

Lindeskog, M., Arneth, A., Bondeau, A., Waha, K., Seaquist, J., Olin, S., and Smith, B.: Implications of accounting for land use in simulations of ecosystem carbon cycling in Africa, Earth Syst. Dyn., 4, 385-407, doi:10.5194/esd-4-385-2013, 2013.

Lindroth, A., F. Lagergren, A. Grelle, L. Klemedtsson, O. Langvall, P. Weslien, and Tuulik, J.: Storms can cause Europe-wide reduction in carbon sink, Glob. Change Biol., 15, 346-355, doi:10.1111/j.1365-2486.2008.01719.x, 2009.

Liu, Y.Y., van Dijk, A.I.J.M., de Jeu, R.A.M., Canadell, J.G., McCabe, M.F., Evans, J.P. and Wang, G.: Recent reversal in loss of global terrestrial biomass, Nat. Clim Change, 5, 470-474, doi:10.1038/NCLIMATE2581, 2015.

Luyssaert, S., Schulze, E.-D., Börner, A., Knohl, A., Hessenmö.ller, D., Law, B.E., Ciais, P. and Grace, J.: Old-growth forests as global carbon sinks, Nature, 455, 213-215, doi:10.1038/nature07276, 2008.

Luyssaert, S., Jammet, M., Stoy, P. ..., Dolman, A.J.: Land management and land-cover change have impacts of similar magnitude on surface temperature, Nat. Clim. Change, 4, 389-393, doi:10.1038/nclimate2196, 2014.

Mori A.S., Lertzman K.P. and Gustafsson L.: Biodiversity and ecosystem services in forest ecosystems: a research agenda for applied forest ecology, J. Appl. Ecol., 54, 12-27, doi:10.1111/1365-2664.12669, 2017.

Pan, Y. D., Birdsey, R. A., Fang, J. Y., Houghton, R., Kauppi, P.E., Kurz, W. A., Phillips, O. L., Shvidenko, A., Lewis, S. L., Canadell, J. G., Ciais, P., Jackson, R. B., Pacala, S.W., McGuire, A. D., Piao, S. L., Rautiainen, A., Sitch, S., and Hayes, D.: A large and persistent carbon sink in the world's forests, Science, 333, 988-993, doi:10.1126/science.1201609, 2011.

Perlin, J.: A forest journey: the story of wood and civilization, The Countryman Press, Vermont, 2005.

Poulter B., et al.: The Global Forest Age dataset and its uncertainties (GFADv1.1), Link to NetCDF File. Available at at https://doi.pangaea.de/10.1594/PANGAEA.897392, Accessed May 14, 2018, 2019.

Pugh, T.A.M., Lindeskog, M., Smith, B., Poulter, B., Arneth, A., Haverd, V., and Calle, L: Role of forest regrowth in global carbon sink dynamics, PNAS, 116, 4382-4387, doi:10.1073/pnas.1810512116, 2019

Sabatini, F.M., Burrascano, S., Keeton, W.S., Levers, C., Lindner, M., Pötzschner, F., ..., Kuemmerle, T.: Where are Europe's last primary forests?, Divers. Distrib., 24, 1426-1439, doi:10.1111/ddi.12778, 2018.

Scherstjanoi, M, Kaplan, J.O., and Lischke, H.: Application of a computationally efficient method to approximate gap model results with a probabilistic approach, Geosci. Model Dev., 7, 1543-1571, doi:10.5194/gmd-7-1543-2014, 2014.

Seidl, R., Schelhaas, M.-J. and Lexer, M.J.: Unraveling the drivers of intensifying forest disturbance regimes in Europe, Glob. Change Biol., 17, 2842-2852, doi: 10.1111/j.1365-2486.2011.02452.x, 2011.

Seiler, C., Hutjes, R., Kruijt, B. and Hickler, T.: The sensitivity of wet and dry tropical forests to climate change in Bolivia, J.

Geophys. Res. Biogeosci., 120. doi: 10.1002/2014JG002749, 2015

Shevliakova, E., Pacala, S. W., Malyshev, S., Hurtt, G. C., Milly, P. C. D., Caspersen, J. P., Sentman, L. T., Fisk, J. P., Wirth, C., and Crevoisier, C.: Carbon cycling under 300 years of land use change: Importance of the secondary vegetation sink, Global Biogeochem. Cy., 23, GB2022. doi:10.1029/2007gb003176, 2009.

Sitch, S., Friedlingstein, P., Gruber, N., Jones, S. D., Murray-Tortarolo, G., Ahlström, A., Doney, S. C., Graven, H., Heinze, C., Huntingford, C., Levis, S., Levy, P. E., Lomas, M., Poulter, B., Viovy, N., Zaehle, S., Zeng, N., Arneth, A., Bonan, G., Bopp, L., Canadell, J. G., Chevallier, F., Ciais, P., Ellis, R., Gloor, M., Peylin, P., Piao, S. L., Le Quéré, C., Smith, B., Zhu, Z., and Myneni, R.: Recent trends and drivers of regional sources and sinks of carbon dioxide, Biogeosciences, 12, 653-679, doi:10.5194/bg-12653-2015, 2015. 
Smith, B., Prentice, C., and Sykes, M. T.: Representation of vegetation dynamics in the modelling of terrestrial ecosystems: comparing two contrasting approaches within European climate space, Global Ecol. Biogeogr., 10, 621-637, doi:10.1046/j.1466822X.2001.t01-1-00256.x, 2001.

Smith, B., Wårlind, D., Arneth, A., Hickler, T., Leadley, P., Siltberg, J., and Zaehle, S.: Implications of incorporating N cycling and $\mathrm{N}$ limitations on primary production in an individual-based dynamic vegetation model, Biogeosciences, 11, 2027-2054, doi:10.5194/bg-11-2027-2014, 2014.

Urban, M. C.: Accelerating extinction risk from climate change, Science, 348, 571-573, doi:10.1126/science.aaa4984, 2015.

Wei, Y., Liu, S., Huntzinger, D. N., Michalak, A. M., Viovy, N., Post, W. M., Schwalm, C. R., et al.: The North American Carbon Program Multi-Scale Synthesis and Terrestrial Model Intercomparison Project - Part 2: Environmental Driver Data, Geosci. Model Dev., 7, 2875-2893, doi:10.5194/gmd-7-2875-2014, 2014.

Zaehle, S., Sitch, S., Prentice, I. C., Liski, J., Cramer, W., Erhard, M., Hickler, T., Smith, B.: The importance of age-related decline in forest NPP for modeling regional carbon balances, Ecol. Appl., 16, 1555-1574, doi:10.1890/10510761(2006)016[1555:TIOADI]2.0.CO;2, 2006.

Zaehle, S. and Dalmonech, D.: Carbon-nitrogen interactions on land at global scales: Current understanding in modelling climate biosphere feedbacks, Curr. Opin. Environ. Sustain., 3, 311-320, doi:10.1016/j.cosust.2011.08.008, 2011. 